\title{
Seasonal variation of fine- and coarse-mode nitrates and related aerosols over East Asia: synergetic observations and chemical transport model analysis
}

\author{
Itsushi Uno ${ }^{1}$, Kazuo Osada ${ }^{2}$, Keiya Yumimoto ${ }^{1}$, Zhe Wang ${ }^{1,3}$, Syuichi Itahashi $^{4}$, Xiaole Pan $^{3}$, Yukari Hara ${ }^{1}$, \\ Yugo Kanaya $^{5}$, Shigekazu Yamamoto ${ }^{6}$, and Thomas Duncan Fairlie ${ }^{7}$ \\ ${ }^{1}$ Research Institute for Applied Mechanics, Kyushu University, Kasuga Park 6-1, Fukuoka, 816-8580, Japan \\ ${ }^{2}$ Nagoya University, Graduate School of Environmental Studies, Furo-cho, Chikusa-ku, Nagoya, 464-8601, Japan \\ ${ }^{3}$ Institute of Atmospheric Physics, CAS, Beijing, China \\ ${ }^{4}$ Central Research Institute of Electric Power Industry, Abiko, Chiba, 270-1194, Japan \\ ${ }^{5}$ Japan Agency for Marine-Earth Science and Technology, 3173-25 Showa-machi, Kanazawa-ku, Yokohama, 236-0001, Japan \\ ${ }^{6}$ Fukuoka Institute of Health and Environmental Sciences, Mukaizano 39, Dazaifu, Fukuoka 818-0135, Japan \\ ${ }^{7}$ NASA, Langley Research Center, Hampton, VA 23681-0001, USA
}

Correspondence to: Itsushi Uno (uno@riam.kyushu-u.ac.jp)

Received: 12 May 2017 - Discussion started: 5 July 2017

Revised: 3 October 2017 - Accepted: 11 October 2017 - Published: 29 November 2017

\begin{abstract}
We analyzed long-term fine- and coarse-mode synergetic observations of nitrate and related aerosols $\left(\mathrm{SO}_{4}^{2-}\right.$, $\left.\mathrm{NO}_{3}^{-}, \mathrm{NH}_{4}^{+}, \mathrm{Na}^{+}, \mathrm{Ca}^{2+}\right)$ at Fukuoka $\left(33.52^{\circ} \mathrm{N}, 130.47^{\circ} \mathrm{E}\right)$ from August 2014 to October 2015. A Goddard Earth Observing System chemical transport model (GEOS-Chem) including dust and sea salt acid uptake processes was used to assess the observed seasonal variation and the impact of long-range transport (LRT) from the Asian continent. For fine aerosols ( $\mathrm{fSO}_{4}^{2-}, \mathrm{fNO}_{3}^{-}$, and $\mathrm{fNH}_{4}^{+}$), numerical results explained the seasonal changes, and a sensitivity analysis excluding Japanese domestic emissions clarified the LRT fraction at Fukuoka $\left(85 \%\right.$ for $\mathrm{fSO}_{4}^{2-}, 47 \%$ for $\mathrm{fNO}_{3}^{-}, 73 \%$ for $\left.\mathrm{fNH}_{4}^{+}\right)$. Observational data confirmed that coarse $\mathrm{NO}_{3}^{-}$ $\left(\mathrm{cNO}_{3}^{-}\right)$made up the largest proportion (i.e., 40-55\%) of the total nitrate (defined as the sum of $\mathrm{fNO}_{3}^{-}, \mathrm{cNO}_{3}^{-}$, and $\mathrm{HNO}_{3}$ ) during the winter, while $\mathrm{HNO}_{3}$ gas constituted approximately $40 \%$ of the total nitrate in summer and $\mathrm{fNO}_{3}^{-}$ peaked during the winter. Large-scale dust-nitrate (mainly $\mathrm{cNO}_{3}^{-}$) outflow from China to Fukuoka was confirmed during all dust events that occurred between January and June. The modeled $\mathrm{cNO}_{3}^{-}$was in good agreement with observations between July and November (mainly coming from sea salt $\mathrm{NO}_{3}^{-}$). During the winter, however, the model underestimated $\mathrm{cNO}_{3}^{-}$levels compared to the observed levels. The rea-
\end{abstract}

son for this underestimation was examined statistically using multiple regression analysis (MRA). We used $\mathrm{cNa}^{+}$, nss$\mathrm{cCa}^{2+}$, and $\mathrm{cNH}_{4}^{+}$as independent variables to describe the observed $\mathrm{cNO}_{3}^{-}$levels; these variables were considered representative of sea salt $\mathrm{cNO}_{3}^{-}$, dust $\mathrm{cNO}_{3}^{-}$, and $\mathrm{cNO}_{3}^{-}$accompanied by $\mathrm{cNH}_{4}^{+}$), respectively. The MRA results explained the observed seasonal changes in dust $\mathrm{CNO}_{3}^{-}$and indicated that the dust-acid uptake scheme reproduced the observed dust-nitrate levels even in winter. The annual average contributions of each component were $43 \%$ (sea salt $\mathrm{cNO}_{3}^{-}$), $19 \%$ (dust $\mathrm{cNO}_{3}^{-}$), and $38 \%\left(\mathrm{cNH}_{4}^{+}\right.$term). The MRA dust- $\mathrm{cNO}_{3}^{-}$ component had a high value during the dust season, and the sea salt component made a large contribution throughout the year. During the winter, $\mathrm{cNH}_{4}^{+}$term made a large contribution. The model did not include aerosol microphysical processes (such as condensation and coagulation between the fine anthropogenic aerosols $\mathrm{NO}_{3}^{-}$and $\mathrm{SO}_{4}^{2-}$ and coarse particles), and our results suggest that inclusion of aerosol microphysical processes is critical when studying observed $\mathrm{cNO}_{3}^{-}$ formation, especially in winter. 


\section{Introduction}

Long-range transboundary transport of dust and pollutants in East Asia, and their complex interactions, is an important environmental issue due to the recent rapid economic developments and changes in these areas (e.g., Lawrence and Lelieveld, 2010; Li et al., 2017; Zhang et al., 2017). Because of the heavy air pollution occurring in China, a great deal of research focuses mainly on fine-mode aerosols (i.e., $\mathrm{PM}_{2.5}$, particle aerodynamic diameter $\left.<2.5 \mu \mathrm{m}\right)$. $\mathrm{NO}_{x}$ emissions have been increasing rapidly over the past decade (e.g., Richter et al., 2005; Irie et al., 2016), and long-range nitrate transport is becoming increasingly important for regional nitrogen budget studies (e.g., Oita et al., 2016; Itahashi et al., 2016, 2017; Uno et al., 2017a, b). A large proportion of nitrate exists in coarse mode $\left(\mathrm{PM}_{\mathrm{c}}\right.$, particle aerodynamic diameter $>2.5 \mu \mathrm{m}$ ) due to interactions with sea salt and mineral dust. The formation of nitrate on dust aerosols has been clearly observed using scanning electron microscopy both in laboratory experiments and using field measurements ( $\mathrm{Li}$ and Shao, 2009). Acid uptake of pollutants over sea salt and dust surfaces is important when evaluating coarse $\mathrm{NO}_{3}^{-}\left(\mathrm{cNO}_{3}^{-}\right)$, as it modifies the chemical lifetime of nitric acid (including atmospheric loading and deposition). Continuous measurement of both fine- and coarse-mode aerosol compositions (including $\mathrm{NO}_{3}^{-}$) is critical for achieving a complete understanding of the fate of air pollutants and changes in the Asian atmospheric environment ( $\mathrm{Li}$ et al., 2012; Pan et al., 2017; Wang et al., 2017a).

Ground-based and airborne aerosol observations have been studied to determine the physics and chemistry of highconcentration events (e.g., Huebert et al., 2003; Jacob et al., 2003; KORUS-AQ, 2016), but the duration of these observational campaigns is typically less than 1 month, which is insufficient for studying seasonal variation. Monitoring projects conducted by the Acid Deposition Monitoring Network in East Asia (EANET, 2014) and Asian Dust and Aerosol Lidar Observation Network (AD-Net; Sugimoto et al., 2008), among others, have been accumulating observational data for over 10 years, but detailed data on hourly aerosol compositions are rarely captured. Long-term aerosol observations (over at least 1 year), including of aerosol composition and with a high time resolution, are required because seasonal changes in Asian monsoons play an important role in the patterns and frequency of long-range pollutant transport; however, no such detailed observational studies have been undertaken to date.

We have made long-term synergetic observations of the behaviors of aerosols around the Chikushi Campus of Kyushu University, located in the suburbs of Fukuoka City $\left(33.52^{\circ} \mathrm{N}, 130.47^{\circ} \mathrm{E}\right.$ ), since October 2013 (Pan et al., 2015, 2016; Itahahsi et al., 2017; Uno et al., 2017a, b; Osada et al., 2016). We used a state-of-the-art aerosol observation instrument to measure both fine- and coarse-mode aerosols. In this study, we report seasonal variation in both fine- and coarse- mode atmospheric aerosols based on long-term synergetic aerosol observations made at $1 \mathrm{~h}$ intervals in Fukuoka, Japan, from August 2014 to October 2015. During this period, several yellow sand and heavy pollutant transport episodes were observed. This paper reports on the major characteristics of anthropogenic aerosols and long-range dust transport, based on observations and chemical transport model (CTM) analysis. We focused on the seasonal variation in fine- and coarsemode long-range nitrate transport.

This report is structured as follows: Sect. 2 documents the observational dataset, Sect. 3 describes the CTM simulation in detail, Sect. 4 discusses temporal variations at observation sites and the model results, and Sect. 5 provides a summary and conclusions.

\section{Observation}

Observations were made on the rooftop (4F) of the Fukuoka Institute of Health and Environmental Science and the Chikushi Campus of Kyushu University, Fukuoka. The horizontal distance between these two sites is about $5 \mathrm{~km}$. Both sites are located in a suburban area of Fukuoka. The anthropogenic activity was very limited at both sites, and the air quality showed similar patterns.

\subsection{Aerosol chemical speciation analyzer and $\mathrm{NH}_{x}$ measurement}

A continuous dichotomous aerosol chemical speciation analyzer (ACSA-12 monitor; Kimoto Electric, Osaka, Japan), was utilized to measure $\mathrm{PM}_{10}$ (particulate matter $<10 \mu \mathrm{m}$ in diameter) and $\mathrm{PM}_{2.5}$ (particulate matter $<2.5 \mu \mathrm{m}$ in diameter) with high temporal resolution (Kimoto et al., 2013). Particulate matter (PM) was collected on a tape filter made of Teflon (PTFE). Hourly observations were conducted to monitor $\mathrm{SO}_{4}^{2-}, \mathrm{NO}_{3}^{-}$, optical black carbon (BC), and watersoluble organic compounds (WSOC) at Fukuoka. The mass concentrations of PM were determined using the beta-ray absorption method. The ACSA-12 measured $\mathrm{NO}_{3}^{-}$and WSOC by an ultraviolet absorption-photometric method and $\mathrm{SO}_{4}^{2-}$ by turbidimetry after the addition of $\mathrm{BaCl}_{2}$ to form $\mathrm{BaSO}_{4}$ and polyvinyl pyrrolidone as a stabilizer. Optical $\mathrm{BC}$ was measured using a near-infrared light scattering method, and the observed data showed a good correlation with the IMPROVE protocol measurement (Hasegawa et al., 2004). The analytical period was within $2 \mathrm{~h}$ of sampling; therefore, the volatilization of particulate $\mathrm{NH}_{4} \mathrm{NO}_{3}$ after collection was regarded as minimal compared with the traditional filter-pack observation method. ACSA has been tested previously (Osada et al., 2016) and used to identify aerosol chemical compositions at Fukuoka (Pan et al., 2016; Uno et al., 2017a, b). It should be noted that ACSA-12 measures both fine- and coarse-mode aerosols simultaneously and is an important for mass budget studies and evaluation of CTMs. 
The behaviors of $\mathrm{NH}_{3}$ and $\mathrm{NH}_{4}^{+}$are also important because they are the counterions for $\mathrm{SO}_{4}^{2-}$ and $\mathrm{NO}_{3}^{-}$. The concentrations of gaseous $\mathrm{NH}_{3}$ and $\mathrm{NH}_{4}^{+}$in fine particles were measured with a semi-continuous microflow analytical system (MF-NH 3 A, Kimoto Electric; Osada et al., 2011). Two inlet lines were used to differentiate the total amounts of $\mathrm{NH}_{x}$ and particulate $\mathrm{NH}_{4}^{+}$after gaseous $\mathrm{NH}_{3}$ was removed using a phosphoric acid-coated denuder from the sample air stream. The cutoff diameter of the inlet impactor was about $2 \mu \mathrm{m}$ (which is smaller than the ACSA $\mathrm{PM}_{2.5}$ cutoff). Secondary inorganic aerosols $\left(\mathrm{SO}_{4}^{2-}, \mathrm{NO}_{3}^{-}\right.$, and $\left.\mathrm{NH}_{4}^{+}\right)$were fully observed using our synergetic monitoring system.

\subsection{Denuder-filter (D-F) pack method}

During our observation period from August 2014 to October 2015, we conducted D-F pack measurements at the Chikushi Campus of Kyushu University, Fukuoka. An annular denuder-multi-stage-filter sampling system was used for $\mathrm{HNO}_{3}$ and size-segregated aerosol sampling. The sampling interval was $6-8 \mathrm{~h}$ for intensive observation and 1-2 days for regular observation. At the inlet, coarse-mode aerosols were removed by nucleopore membrane filters (111114; Nomura Micro Science Co., Ltd., Atsugi, Japan; pore size $=8 \mu \mathrm{m}$ ), and then gas-phase $\mathrm{HNO}_{3}$ was collected with the annular denuder (2000-30x242-3CSS; URG, Chapel Hill, NC, USA) coated with $\mathrm{NaCl}$ (Perrino et al., 1990). Fine-mode aerosols were collected with a PTFE filter (J100A047A; ADVANTEC, Tokyo, Japan; pore size $=1 \mu \mathrm{m})$, and a nylon filter (66509; Pall Co., Port Washington, NY, USA) captured volatilized nitrates from the PTFE filter (Appel et al., 1981; Vecchi et al., 2009). The sample air flow rate was $16.7 \mathrm{~L} \mathrm{~min}^{-1}\left(1 \mathrm{~atm}, 25^{\circ} \mathrm{C}\right)$. Under these conditions, the aerodynamic diameter of the $50 \%$ cutoff for the nucleopore filter was approximately $1.9 \mu \mathrm{m}$ (John et al., 1983). The samples were analyzed by ion chromatography (IC). Finemode aerosols $(<1.9 \mu \mathrm{m}$ in diameter) were underestimated by the D-F pack compared with the ACSA measurement, and coarse-mode aerosols $(>1.9 \mu \mathrm{m}$, with no upper limit) were overestimated by the D-F pack compared with the ACSA $\mathrm{PM}_{\mathrm{c}}$ measurements $(2.5-10 \mu \mathrm{m})$ due to a difference in cutoff diameter between the methods (Osada et al., 2016). Details of the ACSA data comparison and validation were reported previously by Osada et al. (2016).

\section{Numerical modeling}

We used the 3-D Goddard Earth Observing System chemical transport model (GEOS-Chem) (v. 09-02) (Bey et al., 2001; Park et al., 2004; Fairlie et al., 2007, 2010). The model was run with the full GEOS-Chem $\mathrm{NO}_{x}-\mathrm{O}_{x}-\mathrm{VOC}-\mathrm{HO}_{x}-$ $\mathrm{CO}$ chemistry option to simulate the formation of aerosols, including mineral dust, sea salt, and secondary inorganic aerosols $\left(\mathrm{SO}_{4}^{2-}, \mathrm{NO}_{3}^{-}, \mathrm{NH}_{4}^{+}\right)$. We also modeled the emis- sion/transport of primary BC and organic carbon (OC). However, the detailed carbonaceous species and secondary organic aerosol (SOA) options in GEOS-Chem were not used in this study.

Dust in GEOS-Chem is classified according to four size bins (radii of $0.1-1.0,1.0-1.8,1.8-3.0$, and $3.0-6.0 \mu \mathrm{m}$ ), based on Ginoux et al. (2004). The smallest size bin is further divided into four bins (radii 0.1-0.18, 0.18-0.3, $0.3-0.6,0.6-1.0 \mu \mathrm{m})$ for optical properties and heterogeneous chemistry. This model uses the dust entrainment and deposition (DEAD) mobilization scheme from Zender et al. (2003), combined with the source function used in the Goddard Chemistry Aerosol Radiation and Transport (GOCART) model (Ginoux et al., 2001), as described by Fairlie et al. (2007). Several modifications to capture seasonal changes in dust source function, the dust emission fraction within dust bins, and the change in wet scavenging efficiency that was inversely determined to fully capture Asian dust (Yumimoto et al., 2017) were used in this study. The general performance of our dust simulation was already reported by Yumimoto et al. (2017) and Uno et al. (2017a, b). Sea salt is distributed into two size bins (dry radii $0.01-0.5$ and $0.5-8 \mu \mathrm{m}$ ). The sea salt emission scheme is based on the work of Jaeglé et al. (2011) and was well validated by those authors. It includes the effects of sea-surface temperature (SST), as more sea salt is emitted in the summer.

In this study, the reactive uptake of $\mathrm{HNO}_{3}$ and $\mathrm{SO}_{2}$ on dust (limited by dust alkalinity) and the uptake of gasphase $\mathrm{H}_{2} \mathrm{SO}_{4}$ (limited by competition with other aerosol surfaces) (Fairlie et al., 2010) were used. Dust nitrate (mainly $\left.\mathrm{Ca}\left(\mathrm{NO}_{3}\right)_{2}\right)$ was simulated based on the heterogeneous reaction between dust and nitric acid, as follows:

$\mathrm{CaCO}_{3}+2 \mathrm{HNO}_{3} \rightarrow \mathrm{Ca}\left(\mathrm{NO}_{3}\right)_{2}+\mathrm{H}_{2} \mathrm{O}+\mathrm{CO}_{2}$.

As described by Fairlie et al. (2010), the first-order reactive uptake rate constant $(k)$ is calculated according to the uptake coefficient $(\gamma)$ and surface area density of dust particles (A) using the following equation, suggested by Jacob (2000):

$-\frac{\mathrm{d} C}{\mathrm{~d} t}=\left[\frac{r}{D_{\mathrm{g}}}+\frac{4}{c \gamma}\right]^{-1} A C=k C$,

where $C$ is the concentration of gas uptake (e.g., $\mathrm{HNO}_{3}$ ), $r$ is the aerosol particle radius, $D_{\mathrm{g}}$ is the molecular diffusion coefficient, and $c$ is the mean molecular speed. The uptake coefficient depends on the ambient relative humidity $(\mathrm{RH})$, and we used the RH-dependent function in Fig. 1 of Fairlie et al. (2010). More details on dust-nitrate formation from a heterogeneous reaction can be found in Fairlie et al. (2010). A similar heterogeneous reaction to that described by Eq. (1) for sea salt was also included in our calculation.

The model used the assimilated meteorological fields from the GEOS of the NASA Global Modeling and Assimilation Office (GMAO). The model has a horizontal resolution of $2^{\circ} \times 2.5^{\circ}$ for global runs and $0.5^{\circ} \times 0.667^{\circ}$ for Asian 
one-way nesting runs $\left(11^{\circ} \mathrm{S}-55^{\circ} \mathrm{N}, 70-150^{\circ} \mathrm{E}\right)$, both having 47 vertical levels from the surface to $0.01 \mathrm{hPa}$. The lowest model layer thickness was approximately $130 \mathrm{~m}$. We used anthropogenic emissions data from the Emission Database for Global Atmospheric Research (EDGAR, v. 3) (Olivier and Berdowski, 2001) for the global domain and the Regional Emission Inventory in Asia (REAS, v. 2.1) for the Asian domain, as reported by Kurokawa et al. (2013). The REAS $\mathrm{NH}_{3}$ emissions were modified to include seasonal variations in Asia based on Huang et al. (2012) and further changes in winter emissions recommended by Xu et al. (2015). Volcanic $\mathrm{SO}_{2}$ emissions are based on the database of the Japan Meteorological Agency (http://www.data.jma.go.jp/svd/vois/data/ tokyo/volcano.html). The model simulation was conducted from the beginning of December 2013 to the end of October 2015, and results from the first 8 months were used to train the model. Other basic numerical settings were as reported in Uno et al. (2017a, b).

To investigate whether domestic or transboundary air pollution is dominant in Japan, we also performed a sensitivity simulation. Because the quantity of emissions from China was larger than that from Japan, to avoid large nonlinearities in the atmospheric concentration response to emissions variation (e.g., Itahashi et al., 2015) a sensitivity simulation was designed to include a $20 \%$ reduction in all emissions from Japan (defined as JOFF20\%). Based on differences between the baseline simulation (CNTL) and the JOFF20\% simulation, the domestic contribution from Japan (JOFF) was estimated using a multiple of 5 for differences in CNTL and JOFF20\% experiments. We also made a volcanic $\mathrm{SO}_{2}$ sensitivity simulation without volcanic $\mathrm{SO}_{2}$ emissions (VOFF) because the $\mathrm{SO}_{2}$ to $\mathrm{SO}_{4}^{2-}$ formation can be assumed to be linear.

Based on the analysis of PM concentrations, $\mathrm{PM}_{2.5}$ and $\mathrm{PM}_{10}$ were calculated by summing the individual aerosol $\left(\mathrm{SO}_{4}^{2-}, \mathrm{NO}_{3}^{-}, \mathrm{NH}_{4}^{+}, \mathrm{BC}\right.$, and $\left.\mathrm{OC}\right)$, dust, and sea salt components of the model. Hereafter, we denote modeled ammonium nitrate (i.e., $\mathrm{NH}_{4} \mathrm{NO}_{3}$ ) as $\mathrm{A}-\mathrm{NO}_{3}^{-}$, dust nitrate as $\mathrm{D}$ $\mathrm{NO}_{3}^{-}$, sea salt nitrate as $\mathrm{SS}-\mathrm{NO}_{3}^{-}$, and their sum as simply $\mathrm{NO}_{3}^{-}\left(=\mathrm{A}-\mathrm{NO}_{3}^{-}+\mathrm{D}-\mathrm{NO}_{3}^{-}+\mathrm{SS}^{-\mathrm{NO}_{3}^{-}}\right)$.

\section{Results and discussion}

\subsection{Meteorological variation and sea salt}

Figure 1 shows the location of the observation sites, Fukuoka and the Mt. Sakurajima volcano, and the anthropogenic $\mathrm{SO}_{2}$ emission distribution used in the model calculation. Figure 2 shows (a) the daily mean and maximum wind speed, (b) the daily mean temperature, $\mathrm{RH}$, and precipitation in Fukuoka, as observed by the Japan Meteorological Agency, and (c) the observed coarse-mode $\mathrm{Na}^{+}$by D-F, and GEOSChem-simulated coarse-mode sea salt. The GEOS-Chemsimulated coarse-mode sea salt concentration was converted

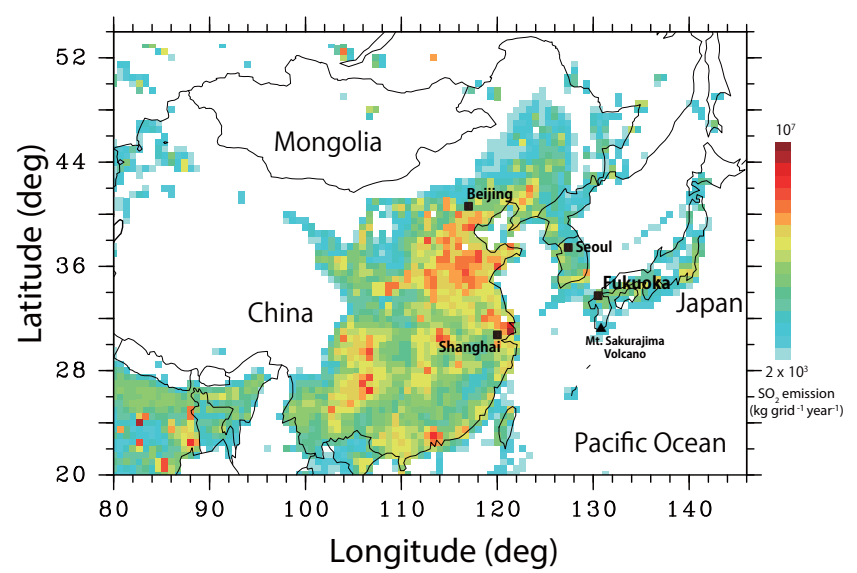

Figure 1. $\mathrm{SO}_{2}$ emissions intensity (based on 2008 data) and observation sites: Fukuoka and Mt. Sakurajima volcano.

to the $\mathrm{Na}$ concentration based on the salinity and $\mathrm{Na}$ mass ratio of seawater (Keene et al., 1986).

Japanese weather is controlled by changes in Asian monsoons. Under summer monsoon conditions (covered by S-SE wind from the hot and moist air mass of the North Pacific High), air temperature and $\mathrm{RH}$ are at their maximum, while during the winter monsoon (N-NW continental cold air outflow) low temperatures and less precipitation are observed in Fukuoka. Maximum wind speeds in excess of $10 \mathrm{~m} \mathrm{~s}^{-1}$ in summer-fall show the effects of typhoons (Fig. 2a). The precipitation difference between August 2014 and August 2015 is important for examining differences in the $\mathrm{NH}_{3}$ concentration (August 2014 had more rainfall than August 2015), and we will discuss this in Sect. 4.3.4.

The time variation of modeled coarse-mode $\mathrm{Na}^{+}$generally agreed well with observations except during typhoon events. There were five typhoons between July and September 2015, and the modeled $\mathrm{cNa}^{+}$was very high compared with observations. This indicated that the sea salt emission scheme for very strong wind conditions was overestimated. We also observed high precipitation during the typhoon events. Another important difference is that the typhoon in 2014 occurred in the fall (September-October), after the SST had cooled, while in 2015 it occurred in the summer (July-August) when the SST was warm and more sea salt was emitted.

\subsection{Daily variation and validation of modeling reproducibility}

The monthly variation depends on the how well the model can reproduce the daily variation in the long-range transport (LRT) from continental Asia to Japan, as well as sporadic dust transport. In this section, we analyzed this short-term daily variation and sporadic dust phenomena and validated the model performance statistically. The monthly (seasonal) variation of aerosols is discussed in Sect. 4.3. 

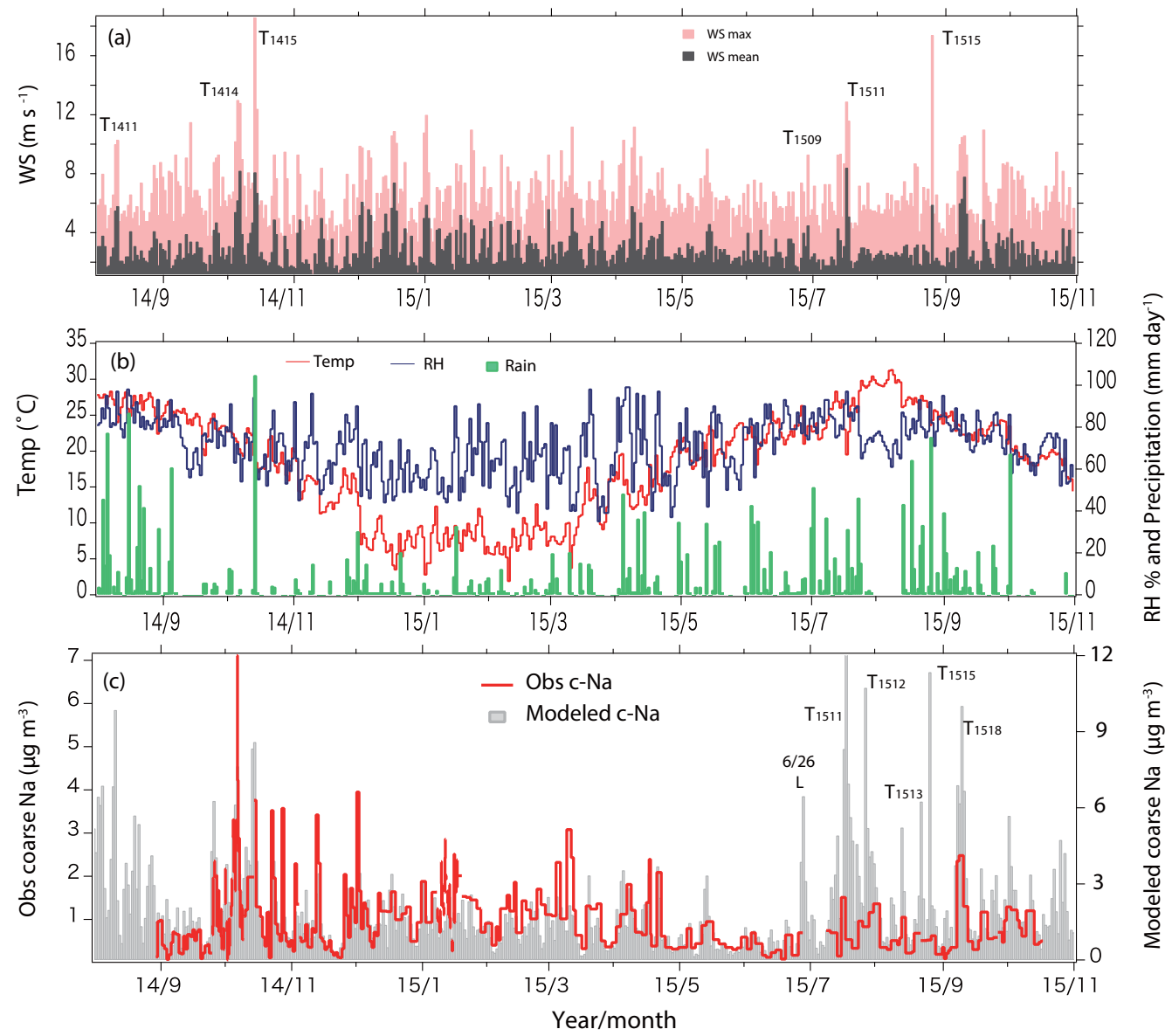

Figure 2. (a) Wind speeds (daily mean and maximum) at Fukuoka. (b) Daily average temperature, relative humidity (RH) and precipitation. (c) Observed coarse $\mathrm{Na}^{+}$and modeled coarse $\mathrm{Na}^{+}$(converted from GEOS-Chem coarse sea salt). T indicates typhoons: T1411 is Halong, T1414 is Fengshen, T1415 is Kalmaegi, T1509 is Chanhom, T1511 is Nangka, T1512 is Halola, T1513 is Soudelor, T1515 is Goni, and T1518 is Etau.

Table 1. Statistical summary of comparisons of the model results with observations between August 2014 and October 2015.

\begin{tabular}{lrrrrrr}
\hline $\begin{array}{l}\text { Concentration } \\
\left(\mu \mathrm{g} \mathrm{m}^{-3}\right)\end{array}$ & $\begin{array}{r}\text { Mean } \\
\text { observation } \\
\left(\mu \mathrm{g} \mathrm{m}^{-3}\right)\end{array}$ & $\begin{array}{r}\text { Mean } \\
\text { model } \\
\left(\mu \mathrm{g} \mathrm{m}^{-3}\right)\end{array}$ & $\begin{array}{r}\text { Normalized mean } \\
\text { bias } \\
(\%)\end{array}$ & $\begin{array}{r}\text { Mean fractional } \\
\text { bias } \\
(\%)\end{array}$ & $\begin{array}{r}\text { Mean fractional } \\
\text { error } \\
(\%)\end{array}$ & $R$ \\
\hline $\mathrm{PM}_{2.5}$ & 17.51 & 11.26 & -35.69 & -46.71 & 53.68 & 0.72 \\
$\mathrm{PM}_{10}$ & 32.52 & 22.34 & -31.31 & -35.74 & 47.98 & 0.66 \\
$\mathrm{BC}^{2-}$ & 0.64 & 0.44 & -31.53 & -38.77 & 61.64 & 0.35 \\
$\mathrm{fSO}_{4}^{2-}$ & 4.62 & 4.55 & -1.53 & -8.95 & 47.99 & 0.68 \\
$\mathrm{fNO}_{3}^{-}$ & 1.38 & 1.26 & -8.47 & -51.00 & 85.75 & 0.68 \\
$\mathrm{CNO}_{3}^{-}$ & 1.01 & 0.83 & -18.16 & -16.92 & 57.70 & 0.42 \\
\hline
\end{tabular}

Figure 3 shows the temporal variation in (a) $\mathrm{PM}_{2.5}$, (b) $\mathrm{PM}_{10}$, (c) optical $\mathrm{BC}$, (d) fine $\mathrm{SO}_{4}^{2-}$, (e) fine $\mathrm{NO}_{3}^{-}$, and (f) $\mathrm{cNO}_{3}^{-}$observations at Fukuoka. The ACSA observations are indicated in blue; D-F pack observations are indicated by the red line (spike-like high peaks during the dust event are due to large particles $>10 \mu \mathrm{m}$, which is the cutoff in ACSA sampling). The figures also include the correspond- ing model values from the model control experiment (CNTL; gray shading). Both the observation and model results are shown as daily averaged values. The modeled $\mathrm{cNO}_{3}^{-}$in (f) is the sum of dust and sea salt nitrates, and yellow shading indicates the modeled dust $\mathrm{cNO}_{3}^{-}\left(\mathrm{D}-\mathrm{cNO}_{3}^{-}\right)$fraction. Table 1 shows the statistical analysis used to determine model repro- 

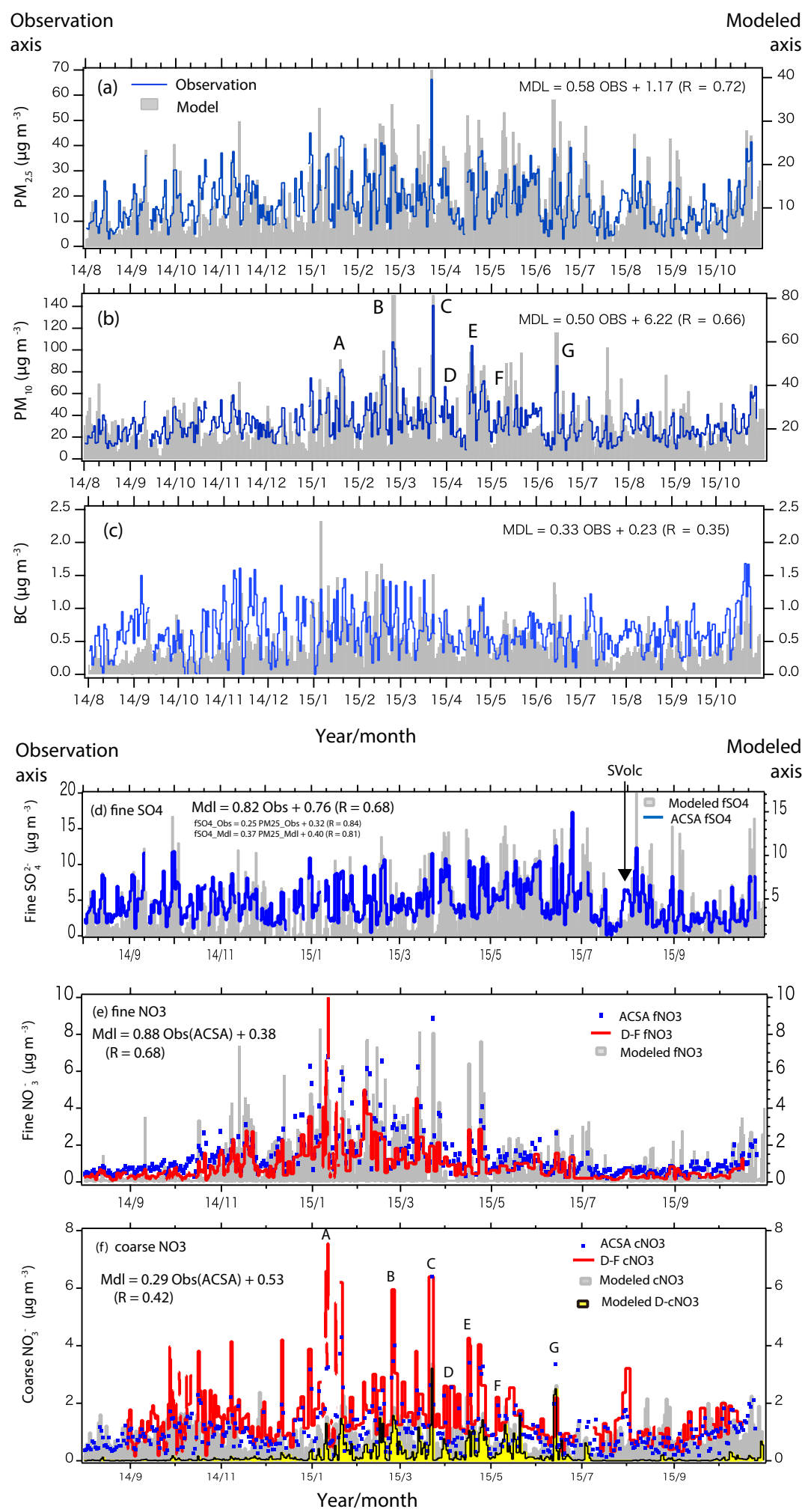

Figure 3. Daily average (a) particulate matter $<2.5 \mu$ m diameter $\left(\mathrm{PM}_{2.5}\right)$, (b) particulate matter $<10 \mu$ m diameter $\left(\mathrm{PM}_{10}\right)$, (c) black carbon (BC), (d) fine $\mathrm{SO}_{4}^{2-}$, (e) fine $\mathrm{NO}_{3}^{-}$, and (f) coarse $\mathrm{NO}_{3}^{-}$. The blue line and dots show aerosol chemical speciation analyzer (ACSA) observations, the red line indicates measurements from the denuder-filter pack (D-F) method, and gray shading indicates the model simulation. D-F data are sampling period averages. Observed data are on the left axis and numerical results are on the right axis, scaled by the regression results (except for panel c). Symbols A-G in panel (b) indicate major dust events in Fukuoka. 
ducibility (results of linear regression are shown within the figure).

The observed $\mathrm{PM}_{2.5}$ clearly exhibited frequent spike-like peaks from winter to early spring, but the frequency decreased after April according to the frequency of "polluted" cold air outbreaks from the Asian continent. The modeled $\mathrm{PM}_{2.5}$ reproduced most of the observed variation. The modeled $\mathrm{PM}_{2.5}$ had a high correlation $\left(\mathrm{PM}_{2.5}\right.$ model $=$ $\left.0.58\left(\mathrm{PM}_{2.5 \_ \text {obs }}\right)+1.16 \mu \mathrm{g} \mathrm{m}^{-3}, R=0.72\right)$ but was underestimated (normalized mean balance $(\mathrm{NMB})=-35.7 \%$ ) because the observation data included aerosol compositions that were not incorporated into the model (e.g., SOAs, many trace metals)

The observed $\mathrm{PM}_{10}$ included coarse aerosols (e.g., dust and sea salt), and peaks corresponded to major dust events. Symbols A-G in Fig. 3b are the major dust events that occurred during our observation period (Uno et al., 2017b). The time variation of modeled $\mathrm{PM}_{10}$ was in good agreement with observations but was consistently underestimated $(\mathrm{NMB}=-31.3 \%)$ for the same reasons as for $\mathrm{PM}_{2.5}$ (i.e., more coarse aerosols were included in the observed data than in the model) and showed some uncertainty for large dust concentrations (Uno et al., 2017b).

The modeled BC was systematically underestimated from July to December but was at reasonable levels during the winter. The modeled BC also shows a similar underestimation (NMB $=-32 \%$ ), although $R$ had a smaller value $(0.34)$ than for $\mathrm{PM}_{2.5}$. One possible explanation is the underestimation of Japanese domestic BC emissions (e.g., Itahashi et al., 2017).

We can see very good agreement for fine $\mathrm{SO}_{4}^{2-}$, with $\mathrm{NMB}=-1.5 \%$ and $R=0.68$. This indicated that the modeled $\mathrm{fSO}_{4}^{2-}$ reproduced most of the observed variation quite well. Figure $3 \mathrm{~d}$ shows intermittently high $\mathrm{SO}_{4}^{2-}$ concentrations. The high $\mathrm{SO}_{4}^{2-}$ levels in the winter depended on the frequency of LRT from the Asian continent based on the synoptic weather change that occurred once or twice a week, while high $\mathrm{SO}_{4}^{2-}$ levels are usually observed in summer (see also Fig. 4b). This is related to the meteorological conditions, i.e., the high $\mathrm{RH}$ in summer. Figure $3 \mathrm{~d}$ shows high $\mathrm{SO}_{4}^{2-}$ levels from the end of July until early August 2015 (designated SVolc in the figure); this was used to demonstrate that the period of volcano impact is important for $\mathrm{SO}_{4}^{2-}$ levels. These high $\mathrm{SO}_{4}^{2-}$ concentrations were due to Japanese domestic emissions and volcanic $\mathrm{SO}_{2}$ emissions. Because volcanic emissions are a natural phenomenon, and the day-byday changes are difficult to predict, the modeled $\mathrm{SO}_{4}^{2-}$ level during SVolc misses the observed peak $\mathrm{SO}_{4}^{2-}$ (see the Appendix for a more detailed analysis).

For $\mathrm{fNO}_{3}^{-}$, the daily maximum reached $6-9 \mu \mathrm{g} \mathrm{m}^{-3}$ and was sometimes higher than the $\mathrm{fSO}_{4}^{2-}$, with the same timing regarding the peaks as for $\mathrm{SO}_{4}^{2-}$. This indicated that $\mathrm{fNO}_{3}^{-}$ was also controlled by LRT from the Asian continent (as discussed by Itahashi et al., 2017, and Uno et al., 2017b):
$\mathrm{NMB}=-8.5 \%$ and $R=0.68$. The correlation is the same as for $\mathrm{fSO}_{4}^{2-}$ but has a larger $\mathrm{NMB}$ than $\mathrm{fSO}_{4}^{2-}$. Coarse $\mathrm{NO}_{3}^{-}$ had a distinct peak value during dust events $\mathrm{A}-\mathrm{G}\left(\mathrm{D}-\mathrm{F} \mathrm{cNO}_{3}^{-}\right.$ levels are higher than $\mathrm{ACSA}_{\mathrm{cNO}}^{-}$levels due to different upper cutoff limits). The modeled $\mathrm{cNO}_{3}^{-}$levels were higher (see Figs. 3c and 4g) during the fall (October to November) because of sea salt $\mathrm{NO}_{3}^{-}$and during the dust season (typically from February to June). Coarse $\mathrm{NO}_{3}^{-}$takes a larger NMB compared with fine $\mathrm{NO}_{3}^{-}$and is underestimated. This can be understood because $\mathrm{cNO}_{3}^{-}$depends on the prediction accuracy of dust and sea salt.

As shown in Fig. 3, a regression slope that is less than 1 could be a natural phenomenon owing to representation issues regarding the model and observations. The GEOSChem model result is an average value over a $0.5^{\circ} \times 0.667^{\circ}$ grid, while the observation is conducted over a station. This is another reason why the simulated model results tend to be underestimated at the high end and overestimated at the low end, which results in a slope less than 1.

For all of the components shown in Table 1, the mean fractional bias (MFB) ranges between -51.0 and $-8.96 \%$, and the mean fractional error (MFE) ranges between 47.99 and $85.75 \%$. Except for $\mathrm{fNO}_{3}^{-}$, these results satisfied the model performance criteria (MFB $< \pm 60 \%$ and MFE $< \pm 75 \%$ ) proposed by Boylan and Russell (2006). Wang et al. (2017b) also reported a similar score for $\mathrm{fNO}_{3}^{-}$for different chemical transport models (CMAQ and NAQPMS) and this may be a limitation of current CTMs.

\subsection{Monthly variation in aerosol compositions}

Figure 4 shows the monthly average (a) $\mathrm{PM}_{2.5}$, (b) fine- and coarse-mode $\mathrm{SO}_{4}^{2-}$, (c) fine and coarse $\mathrm{NH}_{4}^{+}$, (d) $\mathrm{NH}_{3}$ gas, (e) $\mathrm{HNO}_{3}$, (f) total $\mathrm{NO}_{3}^{-},(\mathrm{g})$ coarse $\mathrm{NO}_{3}^{-}$, and (h) fine $\mathrm{NO}_{3}^{-}$ levels. The box-and-whisker plots show the observed fine aerosol levels (10th, 25th, 50th, 75th, and 90th percentile values are marked). The observed average monthly coarse-mode aerosols are shown by the red dashed line. The modeled average monthly fine aerosol concentration for the CNTL is depicted by the straight black line and for the JOFF by the black dashed line.

\subsubsection{Fine-mode $\mathrm{SO}_{4}^{2-}$ and $\mathrm{NH}_{4}^{+}$}

The modeled $\mathrm{SO}_{4}^{2-}$ results explained the observed temporal variation and corresponded to approximately $37 \%$ of the modeled $\mathrm{PM}_{2.5}$ concentration (daily base regression: $\mathrm{SO}_{4 \text { model }}^{2-}=0.82\left(\mathrm{SO}_{4 \text { obs }}^{2-}\right)+0.76 \mu \mathrm{g} \mathrm{m}^{-3}, \quad R=0.68$; $\mathrm{SO}_{4}^{2-}$ model $\left.=0.37\left(\mathrm{PM}_{2.5}{ }_{\text {model }}\right)+0.40 \mu \mathrm{g} \mathrm{m}^{-3}, \quad R=0.81\right)$. The high correlation suggests that the variations in $\mathrm{PM}_{2.5}$ were mainly driven by $\mathrm{fSO}_{4}^{2-}$, as a main component of $\mathrm{PM}_{2.5}$ for both the observations and the model. The model underestimated $\mathrm{fSO}_{4}^{2-}$ levels from December to January. Similar underestimation was observed in other CTM appli- 

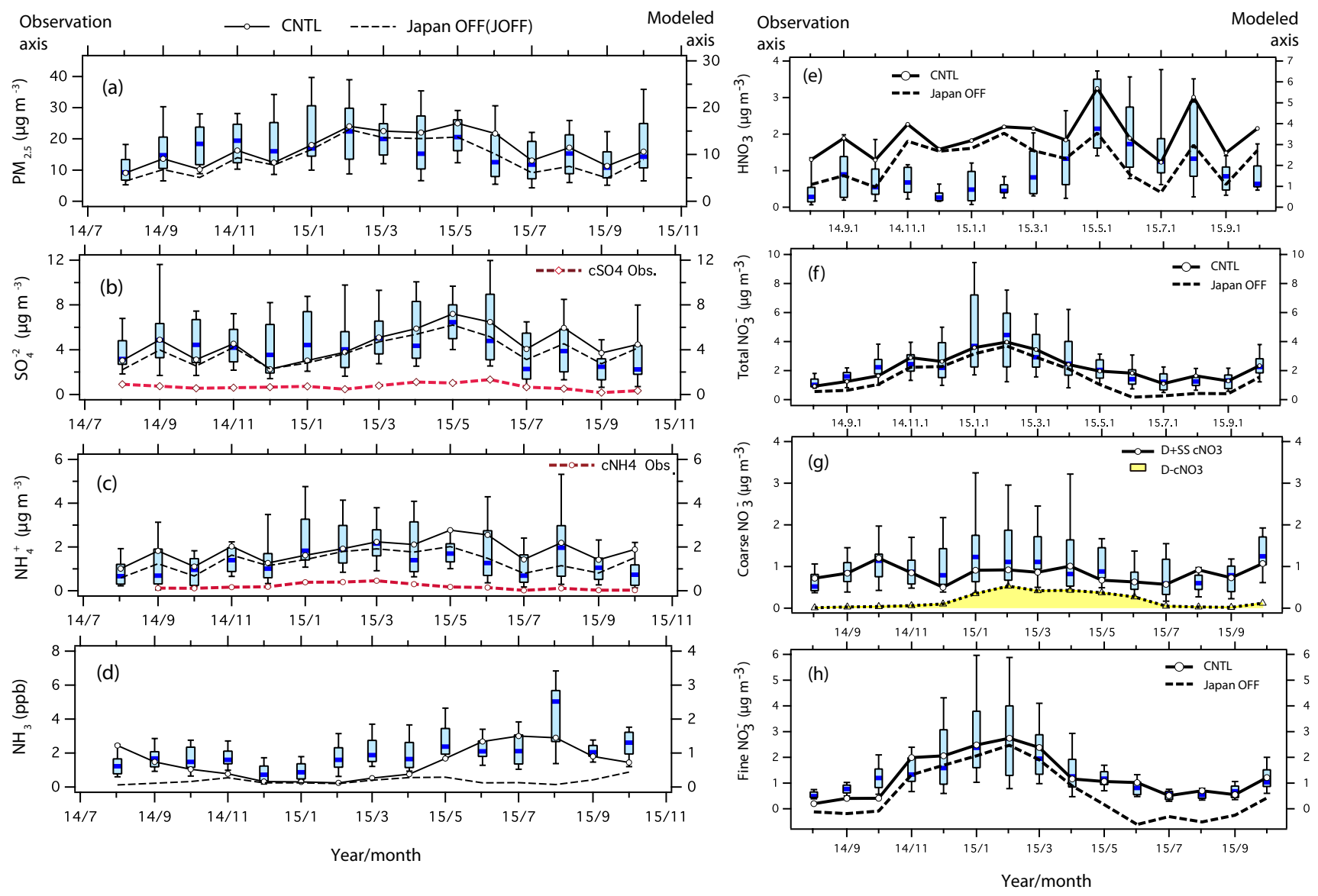

Figure 4. Monthly average plots of (a) $\mathrm{PM}_{2.5}$, (b) fine $\mathrm{SO}_{4}^{2-}$, (c) fine $\mathrm{NH}_{4}^{+}$, and (d) $\mathrm{NH}_{3}$ gas, (e) $\mathrm{HNO}_{3}$, (f) total $\mathrm{NO}_{3}^{-}$, (g) coarse $\mathrm{NO}_{3}^{-}$, and (h) fine $\mathrm{NO}_{3}^{-}$. Box-and-whisker plots show observations (10th, 25th, 50th, 75th, 90th percentile values). Red lines in panels (b) and (c) show ACSA-observed coarse-mode concentrations. Black lines are modeled monthly averages; the black straight line indicates the baseline model (CNTL), and the black dashed line except (g) indicates the sensitivity experiment of Japanese emission reduction (JOFF). For (g), the black dashed line shows the modeled dust coarse $\mathrm{NO}_{3}^{-}\left(\mathrm{D}-\mathrm{cNO}_{3}^{-}\right)$. $\mathrm{HNO}_{3}$ observations are from D-F, and $\mathrm{NO}_{3}^{-}$observations are from $\mathrm{ACSA}$.

cations (Wang et al., 2017b; Itahashi et al., 2017) and in the observations of He et al. (2014).

Based on Fig. 4, $\mathrm{SO}_{4}^{2-}$ and $\mathrm{NH}_{4}^{+}$levels are reasonably well predicted by the model. The JOFF sensitivity analysis showed that the contribution from Japanese emissions was small and the majority of $\mathrm{SO}_{4}^{2-}$ came from LRT from outside of Japan (annual mean Japanese domestic contribution $=15 \%$ ). For $\mathrm{NH}_{4}^{+}$, we found that the LRT contribution was large until April, after which the Japanese contribution increased as $\mathrm{NH}_{3}$ emissions increased (annual mean Japanese domestic contribution $=27 \%$ ).

Observed coarse mode $\mathrm{SO}_{4}^{2-}$ was about $0.1-0.2$ of observed fine $\mathrm{SO}_{4}^{2-}$ (monthly average relationship: $\mathrm{cSO}_{4}^{2-}$ Obs $=0.185 \mathrm{fSO}_{4}^{2-}$ Obs $-0.052 \mu \mathrm{g} \mathrm{m}^{-3}, \quad R=0.66$ ). The coarse $\mathrm{SO}_{4}^{2-}$ contribution cannot be ignored in winter. Modeled $\mathrm{cSO}_{4}^{2-}$ levels were very small compared to observed levels and are not shown in the figure.

\subsubsection{Fine-mode $\mathrm{NO}_{3}^{-}$}

The modeled $\mathrm{fNO}_{3}^{-}$reproduced the major monthly variation seen in the observed levels. $\mathrm{fNO}_{3}^{-}$levels are higher during the winter and lower during the summer, exhibiting clear seasonal changes. The winter (DJF) $\mathrm{fNO}_{3}^{-}$average was $2.62 \pm 1.64 \mu_{\mathrm{g} \mathrm{m}}^{-3}$. The JOFF sensitivity analysis also confirmed that the majority of $\mathrm{fNO}_{3}^{-}$can be considered due to LRT from outside Japan during the winter. In the summer, $\mathrm{fNO}_{3}^{-}$is minimal because the $\mathrm{NH}_{4} \mathrm{NO}_{3}$ equilibrium between $\mathrm{NH}_{3}$ and $\mathrm{HNO}_{3}$ shifts to the gaseous phase under warm conditions. This phase shift is a function of temperature and $\mathrm{RH}$, and it moves to an aerosol phase at cold temperatures. The monthly average $\mathrm{fNO}_{3}^{-}$from June to September was $0.68 \pm 0.34 \mu \mathrm{g} \mathrm{m}^{-3}$. It should be noted that $\mathrm{NO}_{3}^{-}$measurement by ACSA was finished within $2 \mathrm{~h}$ of PTFE sampling, so any artifact due to the volatilization of $\mathrm{NO}_{3}^{-}$from the Teflon filter surface was small (e.g., Osada et al., 2016). As described in Sect. 2, D-F measurement used the nylon backup 


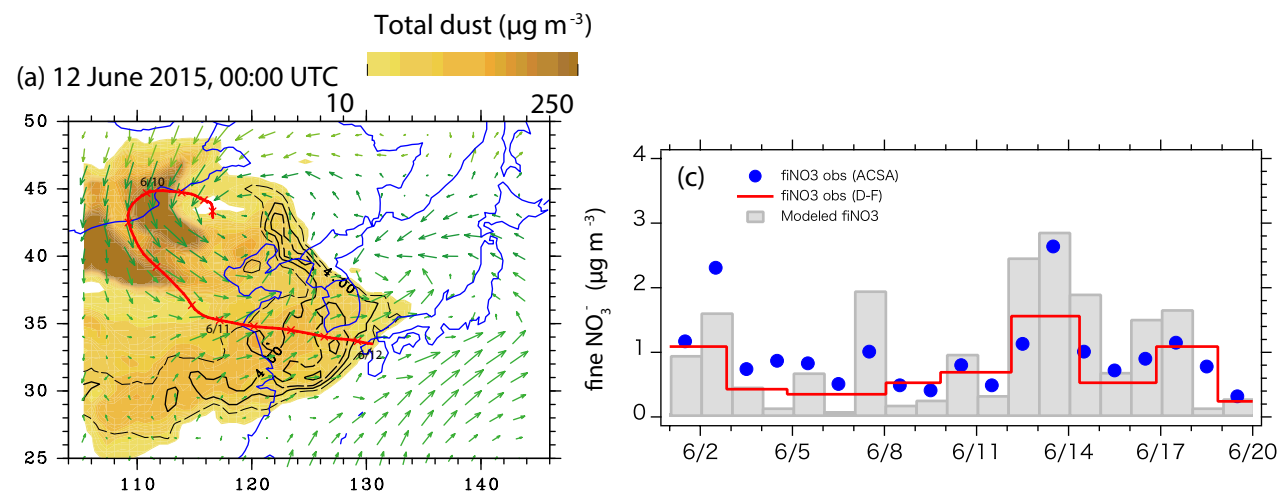

(b) 13 June 2015, 00:00 UTC
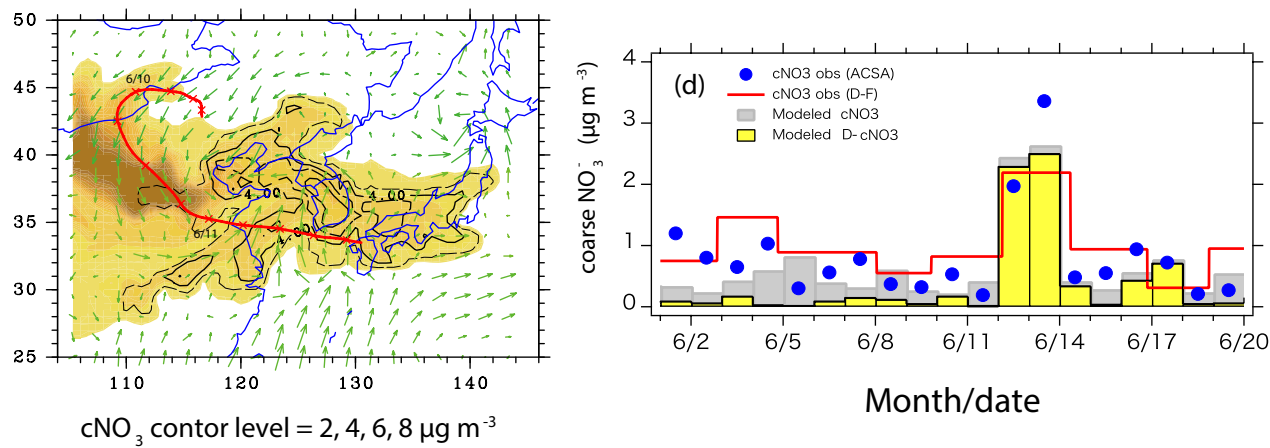

Figure 5. Horizontal distribution of dust (sum of all dust bins) (yellow color) and coarse $\mathrm{NO}_{3}^{-}$(contour) with wind vectors for (a) 12 June, (b) 13 June, and the time variation of daily average (c) fine $\mathrm{NO}_{3}^{-}$and (d) coarse $\mathrm{NO}_{3}^{-}$.

filter to catch the volatilized $\mathrm{HNO}_{3}$ from the Teflon filter surface. Thus, both ACSA $\mathrm{fNO}_{3}^{-}$and D-F $\mathrm{fNO}_{3}^{-}$measurements showed consistent concentrations during the summer (aver-

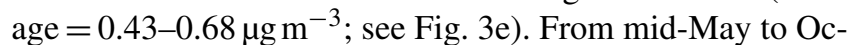
tober, the Japanese contribution becomes dominant (annual mean Japanese domestic contribution $=53 \%$ ).

\subsubsection{Coarse-mode $\mathrm{NO}_{3}^{-}$}

Figure $4 \mathrm{~g}$ shows the clear seasonal cycle of modeled $\mathrm{cNO}_{3}^{-}$. The modeled results showed that dust-nitrate concentrations increased during dust episodes. Modeled sea salt nitrate was consistently in the order of $0.5-1.0 \mu \mathrm{g} \mathrm{m}^{-3}$ as the baseline $\mathrm{cNO}_{3}^{-}$, and it was dominant except during the dust season (showing good agreement with observed values).

Table 2 summarizes the comparison of $\mathrm{cNO}_{3}^{-}$levels. Except for January to June, sea salt $\mathrm{NO}_{3}^{-}$was dominant within $\mathrm{cNO}_{3}^{-}$, and the model results were in good agreement with actual observations. From January to June, the ratio of D$\mathrm{cNO}_{3}^{-}$to $\mathrm{SS}_{-} \mathrm{cNO}_{3}^{-} \approx 1: 1$ and the modeled total $\mathrm{cNO}_{3}^{-}$corresponded to two-thirds of the observed total $\mathrm{cNO}_{3}^{-}$(annual average ratio of $\mathrm{D}_{-} \mathrm{cNO}_{3}^{-}$to $\mathrm{SS}_{-} \mathrm{cNO}_{3}^{-} \approx 1: 2.4$ ). From January to June 2015, we observed several dust events (designated A-G). Uno et al. (2017b) described the typical onset of dust events $\mathrm{B}$ and $\mathrm{C}$ and pointed out underestimation of the modeled $\mathrm{cNO}_{3}^{-}$during these cold dust cases. In this paper, we examine dust event $\mathrm{G}$ as a case study of warm weather dust-acid uptake validation.

Figure 5 shows the daily changes in dust (colored region) and total $\mathrm{D}-\mathrm{cNO}_{3}^{-}$(contoured area) horizontal distributions from (a) 12 June to (b) 13 June and the Hybrid Single Particle Lagrangian Integrated Trajectory (HYSPLIT) model back trajectory starting from Fukuoka. It also shows a comparison of modeled and observed (c) fine- and (d) coarse-mode $\mathrm{NO}_{3}^{-}$. The dust transport path was very similar to those of dust events B and C, as described by Uno et al. (2017b). For dust events $\mathrm{B}$ and $\mathrm{C}$ (see Fig. 3f), modeled $\mathrm{cNO}_{3}^{-}$was underestimated, but for dust event $\mathrm{G}$ modeled $\mathrm{cNO}_{3}^{-}$levels were in good agreement with observed levels. Modeled results show that $\mathrm{D}-\mathrm{cNO}_{3}^{-}$mainly formed over the Yellow Sea and the East China Sea. This indicates that the underestimation of dust $\mathrm{NO}_{3}^{-}$over the winter was independent of the dust-acid uptake scheme. These results indicate the importance of further studies on the mechanism of $\mathrm{cNO}_{3}^{-}$formation.

\subsubsection{Monthly variation in total $\mathrm{NO}_{3}$ and $\mathrm{NH}_{x}$}

Figure 6 shows the observed monthly variation in (a) $\mathrm{fNH}_{4}^{+}$, $\mathrm{cNH}_{4}^{+}$, and $\mathrm{NH}_{3}$; (b) $\mathrm{fNO}_{3}^{-}, \mathrm{cNO}_{3}^{-}$, and $\mathrm{HNO}_{3}$; and (c) the relative mass fraction of $\mathrm{NO}_{3}^{-}$and $\mathrm{HNO}_{3}$. In this figure, $\mathrm{fNO}_{3}^{-}$clearly showed the highest concentration in winter, while $\mathrm{HNO}_{3}$ increased in summer $\left(\mathrm{HNO}_{3}\right.$ accounted for 30 
Table 2. Comparison of coarse-mode $\mathrm{NO}_{3}^{-}$levels $\left(\mu \mathrm{g} \mathrm{m}^{-3}\right)$

\begin{tabular}{lr|rrr|rrr}
\hline \multirow{2}{*}{ Period } & Observation & \multicolumn{3}{c|}{$\mathrm{CTM}$} & \multicolumn{3}{c}{ Mult. regress. analysis } \\
\cline { 2 - 8 } & $\mathrm{cNO}_{3}^{-}$ & $\mathrm{D}_{-} \mathrm{cNO}_{3}^{-}$ & $\mathrm{SS}_{-}-\mathrm{NO}_{3}^{-}$ & Total cNO$_{3}^{-}$ & $\mathrm{D}-\mathrm{cNO}_{3}^{-}$ & $\mathrm{SS}_{-} \mathrm{cNO}_{3}^{-}$ & $\mathrm{cNH}_{4}$ \\
\hline January-June & $1.29^{\mathrm{a}}(1.82)^{\mathrm{b}}$ & 0.40 & 0.43 & 0.83 & 0.34 & 0.46 & 0.68 \\
September-December, July & $0.94(1.37)$ & 0.06 & 0.73 & 0.79 & 0.11 & 0.50 & 0.26 \\
Annual c $^{\mathrm{c}}$ & $1.13(1.61)$ & 0.24 & 0.58 & 0.82 & 0.24 & 0.48 & 0.49 \\
\hline
\end{tabular}

${ }^{a}$ ACSA observation. ${ }^{b}$ D-F observation. ${ }^{c}$ Average level between September 2014 and July 2015 (excluding typhoon period)
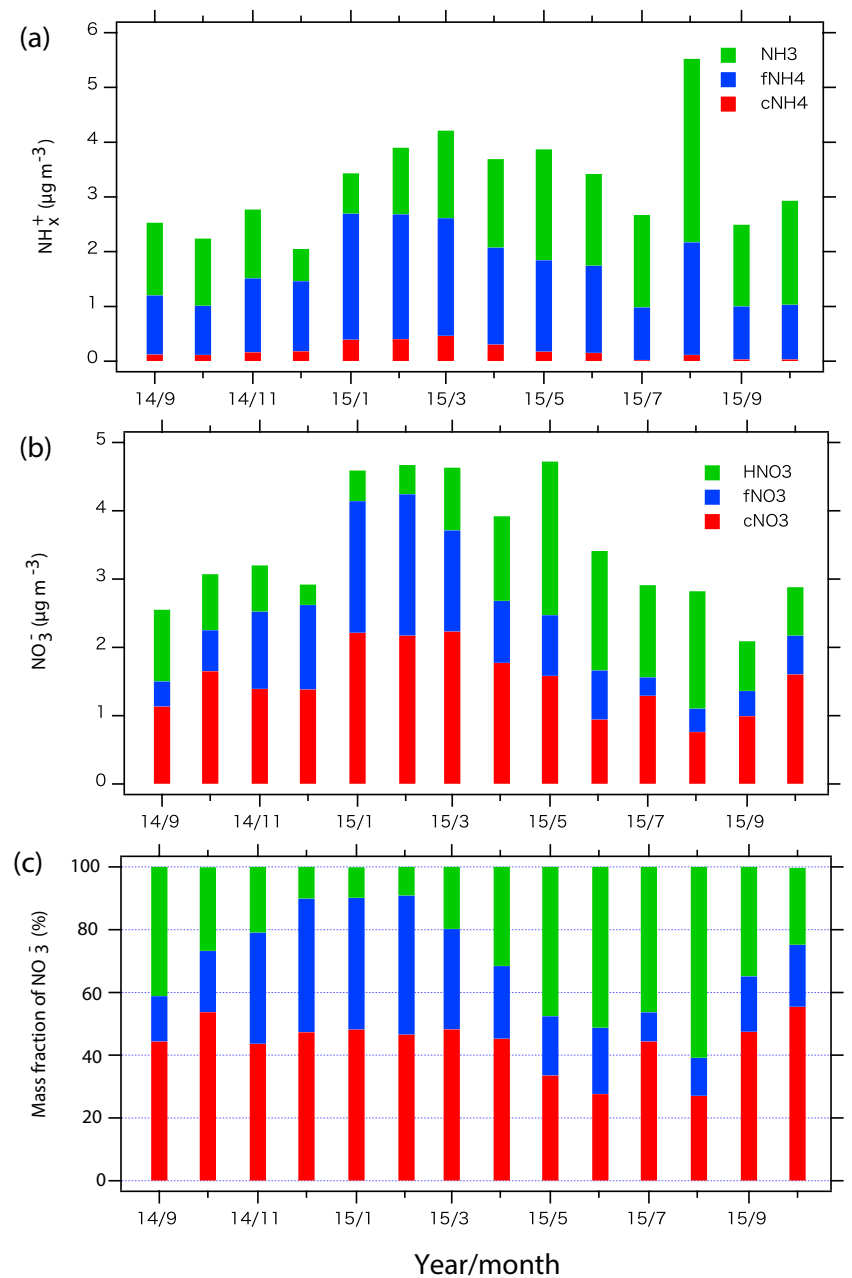

Figure 6. Monthly average values for (a) $\mathrm{NH}_{x}$, (b) $\mathrm{NO}_{3}$, and (c) the mass fraction $(\%)$ of $\mathrm{NO}_{3}$, observed by D-F.

$40 \%$ of total $\mathrm{NO}_{3}^{-}$); this was due to the change in thermal equilibrium between gases and particles. Notably, $\mathrm{cNO}_{3}^{-}$was always higher than $\mathrm{fNO}_{3}^{-}\left(\mathrm{cNO}_{3}^{-}\right.$made up $27-55 \%$ of the total $\mathrm{NO}_{3}^{-}$, and it exceeded $45 \%$ in winter). We observed $0.5-1.0 \mu \mathrm{g} \mathrm{m}^{-3}(0.2-0.4 \mathrm{ppb})$ of $\mathrm{HNO}_{3}$ even in winter.

The observations showed that fine $\mathrm{NH}_{4}^{+}$is higher throughout the year, and the $\mathrm{NH}_{3}$ gas level exceeded $1 \mu \mathrm{g} \mathrm{m}{ }^{-3}$ $(0.4 \mathrm{ppb})$, even in winter. This high $\mathrm{NH}_{3}$ concentration may be influenced by local agriculture and poultry farming 5$10 \mathrm{~km}$ south of the observation site. The high $\mathrm{NH}_{3}$ concentration (see Fig. 4d) in August 2015 (3-4 times higher than in August 2014) might be due to differences in the high temperature (the monthly mean was $28.4^{\circ} \mathrm{C}$, which was $1.7^{\circ} \mathrm{C}$ higher than in 2014) and less precipitation (month total was $186 \mathrm{~mm}$, which was $228 \mathrm{~mm}$ smaller than in 2014). Roelle et al. (2002) indicated that the $\mathrm{NH}_{3}$ emission from soil increased exponentially as soil temperature increased, and due to precipitation more soil water fills the pores in the soil matrix and hinders the diffusion of $\mathrm{NH}_{3}$ from the soil to the air. Their results suggested that our observed meteorological conditions in each year can explain the $\mathrm{NH}_{3}$ concentration variation. The annual average $\mathrm{cNH}_{4}^{+} /$total $\mathrm{NH}_{x}$ ratio was $10 \%$, but it increased to $15 \%$ (JFM average). This indicates that the $\mathrm{cNH}_{4}^{+}$counterpart in winter is important for understanding $\mathrm{CNO}_{3}^{-}$and $\mathrm{cSO}_{4}^{2-}$.

The model results underestimated $\mathrm{NH}_{3}$ (Fig. 4d) and overestimated $\mathrm{HNO}_{3}$ (Fig. 4e); however, the modeled total $\mathrm{NO}_{3}^{-}$, $\mathrm{fNO}_{3}^{-}$and $\mathrm{fNH}_{4}^{+}$levels were in good agreement with the observed values (compared with Fig. 4h, g, and c, respectively). The $\mathrm{NH}_{3}$ emissions inventory is at $25 \mathrm{~km}$ resolution and cannot reflect the impact of local agriculture and poultry farming, which has large uncertainty; this results in the underestimation of $\mathrm{NH}_{3}$ emissions in our study. However, most of the $\mathrm{cNO}_{3}^{-}$formation occurred before arrival in Japan (it occurred mainly over the ocean) and was also not very sensitive to local $\mathrm{NH}_{3}$ emissions.

The present model does not include the formation scheme of $\mathrm{cNH}_{4}^{+}$. The counterparts of $\mathrm{cNH}_{4}^{+}$can be $\mathrm{cNO}_{3}^{-}$and $\mathrm{cSO}_{4}^{2-}$, and this is one of the reasons for $\mathrm{cNO}_{3}^{-}$underestimation by the model. It is important to describe the possible reasons for this underestimation to conduct a detailed $\mathrm{N}$ budget study, because the $\mathrm{cNO}_{3}^{-}$fraction is very large. Another interesting question is whether the modeled acid uptake scheme can explain the observed $\mathrm{cNO}_{3}^{-}$levels in dust and sea salt. We used statistical analysis to investigate this.

\subsection{Statistical analysis of coarse-mode $\mathrm{NO}_{3}^{-}$}

Major sources of $\mathrm{cNO}_{3}^{-}$include dust, sea salt, and other sources, represented as $\mathrm{cNH}_{4}^{+}$. We conducted multiple regression analysis (MRA) to analyze $\mathrm{cNO}_{3}^{-}$. We included 

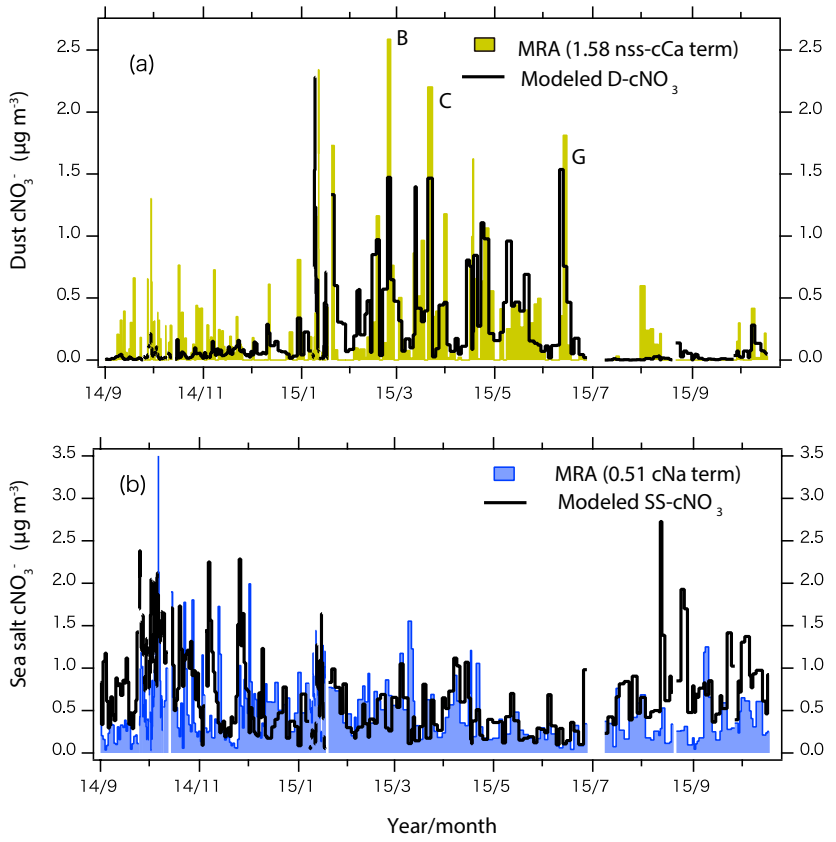

Figure 7. (a) $\mathrm{D}_{-} \mathrm{cNO}_{3}^{-}$estimated by multiple regression analysis and modeled $\mathrm{D}-\mathrm{cNO}_{3}^{-}$; (b) the same parameters for sea salt $\mathrm{NO}_{3}^{-}$. Modeled results averaged over the same time period as for the D-F measurements.

$\mathrm{cNa}^{+}$, non-sea-salt $\mathrm{cCa}^{2+}$ (nss- $\left.\mathrm{CCa}^{2+}\right)$, and $\mathrm{cNH}_{4}^{+}$as independent variables to describe the observed $\mathrm{cNO}_{3}^{-}\left(\mathrm{cSO}_{4}^{2-}\right.$ was excluded from the MRA due to its strong colinearity with $\mathrm{cNH}_{4}^{+}$). One important point is that the observation site is surrounded by school grounds and a large city park, providing background local dust. We found that the median value of nss- $\mathrm{cCa}^{2+}$ during the non-dust season was $0.25 \mu \mathrm{g} \mathrm{m}^{-3}$, and the residence time of local dust coming to the observation site for producing $\mathrm{CNO}_{3}^{-}$was short $(<1 \mathrm{~h})$. We excluded observations less than nss-cCa ${ }^{2+}$ $<0.25 \mu \mathrm{g} \mathrm{m}{ }^{-3}$ from the MRA.

The result of the MRA $\left(n=160, \mathrm{nss}-\mathrm{cCa}>0.25 \mu \mathrm{g} \mathrm{m}^{-3}\right)$ was $\quad \mathrm{cNO}_{3}^{-}=0.51 \mathrm{cNa}^{+}+1.58 \mathrm{nss}-\mathrm{cCa}^{2+}+2.2 \mathrm{cNH}_{4}^{+}+$ $0.19 \mu \mathrm{g} \mathrm{m}^{-3}\left(R^{2}=0.74, p<0.001\right)$, where the term on the right can be considered to represent SS-cNO${ }_{3}^{-}, \mathrm{D}-\mathrm{cNO}_{3}^{-}$, and $\mathrm{cNO}_{3}^{-}$accompanied by $\mathrm{cNH}_{4}^{+}$, respectively.

Figure 7 shows the contribution of (a) MRA D$\mathrm{cNO}_{3}^{-}=1.58 \times \mathrm{nss}^{-} \mathrm{cCa}^{2+}$ for nss-cCa ${ }^{2+}>0.25 \mu \mathrm{g} \mathrm{m}^{-3}$ and (b) MRA SS- $\mathrm{cNO}_{3}^{-}=0.51 \times \mathrm{cNa}^{+}$. The figure also includes the GEOS-Chem modeled results (averaged over the same time period as for the D-F measurements). MRA D-cNOshowed good agreement with modeled $\mathrm{D}-\mathrm{cNO}_{3}^{-}$levels (except for intensive dust events $\mathrm{B}$ and $\mathrm{C}$ ), and this indicates that the dust-acid uptake scheme explains the observed dustnitrate formation (underestimation for $\mathrm{B}$ and $\mathrm{C}$ also comes from the underestimation of modeled dust concentrations). As previously pointed out, modeled $\mathrm{SS}_{-}-\mathrm{NO}_{3}^{-}$was over-

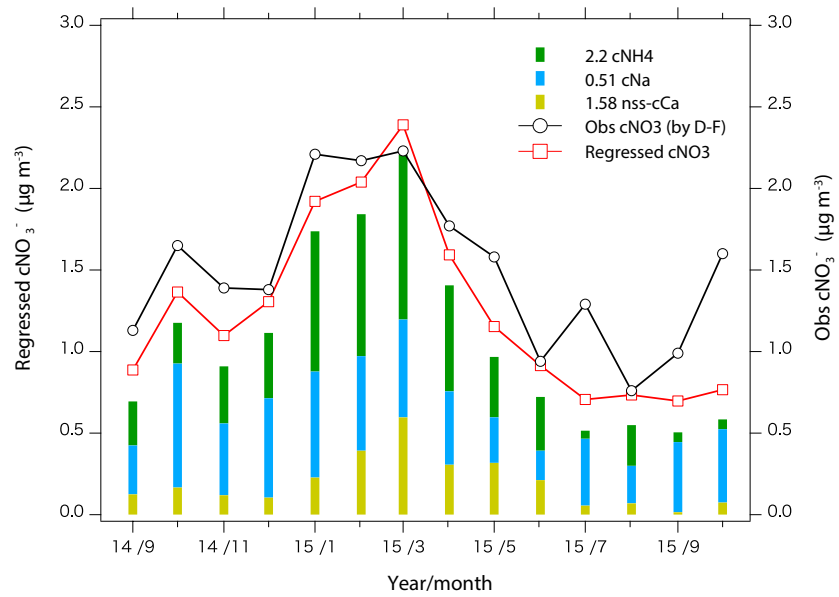

Figure 8. Monthly average multiple regression results for the dust $\mathrm{cNO}_{3}^{-}$, sea salt $\mathrm{cNO}_{3}^{-}$, and $\mathrm{cNH}_{4}^{+}$-related components.

predicted during the summer typhoon period; aside from these periods, good agreement was found with sea salt $\mathrm{cNO}_{3}$ (Fig. 7b).

Figure 8 shows the monthly averaged MRA results and clearly explains the observed seasonal variation. Table 2 summarizes each term and shows the comparison with CTM. The average annual contribution of each term was $40 \%$ for SS- $\mathrm{cNO}_{3}^{-}, 20 \%$ for $\mathrm{D}-\mathrm{cNO}_{3}^{-}$, and $40 \%$ for $\mathrm{cNH}_{4}^{+}$term. The $\mathrm{D}-\mathrm{cNO}_{3}^{-}$value was high during the dust season, and the sea salt component made the largest contribution throughout the year. The $\mathrm{cNH}_{4}^{+}$term made a large contribution during the winter, and one possible reason for this is the condensation/coagulation of small $\mathrm{NH}_{4} \mathrm{NO}_{3}$ and $\left(\mathrm{NH}_{4}\right)_{2} \mathrm{SO}_{4}$ particles onto large particles (e.g., sea salt and dust). The annual average $\mathrm{D}-\mathrm{cNO}_{3}^{-}$to $\mathrm{SS}_{-} \mathrm{cNO}_{3}^{-}$ratio in MRA was $1: 2$, which is close to the modeled ratio $(1: 2.4)$, as shown in Table 2 .

Our results suggest that inclusion of aerosol microphysical processes (such as condensation and coagulation of the fine anthropogenic aerosols $\mathrm{NO}_{3}^{-}$and $\mathrm{SO}_{4}^{2-}$ onto the coarse particles) is important for exploring the observed $\mathrm{cNO}_{3}^{-}$concentrations. A CTM incorporating advanced particle microphysics is one potential option (Yu and Luo, 2014). Such a modeling approach, incorporating interactions with mineral dust and sea salt, has not yet been fully explored in East Asia and is a future research direction.

\section{Conclusions}

Long-term synergetic fine- and coarse-mode aerosol observations were analyzed at $1 \mathrm{~h}$ intervals in Fukuoka, Japan, from August 2014 to October 2015. A GEOS-Chem chemical transport model including dust and sea salt acid uptake processes was used for detailed analysis of observation data to understand the effects of LRT from the Asian continent. The findings from this study can be summarized as follows: 
1. Continuous measurement of $\mathrm{SO}_{4}^{2-}, \mathrm{NO}_{3}^{-}$, and optical BC with the ACSA-12 monitor and of $\mathrm{NH}_{4}^{+}$and $\mathrm{NH}_{3}$ with a semi-continuous microflow analytical system (MF-NH3A), in addition to D-F pack/IC analysis, established a long-term synergetic fine- and coarse-mode aerosol database in Fukuoka, Japan.

2. During the observation period, several Asian dust and long-range anthropogenic aerosol transport events were observed, and a numerical model generally explained the observed temporal variation. A dust concentration by dust emission inversion scheme effectively reproduced the major dust onset.

3. Numerical results explained the seasonal changes in fine aerosols $\left(\mathrm{SO}_{4}^{2-}, \mathrm{NO}_{3}^{-}\right.$, and $\left.\mathrm{NH}_{4}^{+}\right)$and the impact of LRT, and a sensitivity analysis excluding Japanese domestic emissions revealed the LRT fraction ( $85 \%$ for $\mathrm{fSO}_{4}^{2-}, 47 \%$ for $\mathrm{fNO}_{3}^{-}$, and $73 \%$ for $\mathrm{fNH}_{4}^{+}$).

4. Observational data for $\mathrm{HNO}_{3}, \mathrm{fNO}_{3}^{-}$, and $\mathrm{cNO}_{3}^{-}$confirmed that there was a large amount of coarse $\mathrm{NO}_{3}^{-}$ comprising $40-55 \%$ of total nitrate during the winter; meanwhile, $\mathrm{HNO}_{3}$ gas made up $40 \%$ of total nitrate in summer, and fine $\mathrm{NO}_{3}^{-}$peaked during the winter. A numerical model reproduced the seasonal variation in fine $\mathrm{NO}_{3}^{-}$. For coarse $\mathrm{NO}_{3}^{-}$, modeled $\mathrm{cNO}_{3}^{-}$was in good agreement with observations between July and November (mainly coming from sea salt $\mathrm{NO}_{3}^{-}$).

5. Large-scale dust-nitrate outflow from China to Fukuoka was confirmed in all dust events. During the winter, modeled coarse $\mathrm{NO}_{3}^{-}$was underestimated compared to the observed levels.

6. The coarse $\mathrm{NO}_{3}^{-}$underestimation was examined statistically using MRA. We included $\mathrm{cNa}^{+}, \mathrm{nss}^{-\mathrm{CCa}^{2+}}$, and $\mathrm{cNH}_{4}^{+}$as independent variables to describe the observed $\mathrm{cNO}_{3}^{-}$; these terms can be considered to represent SS$\mathrm{cNO}_{3}^{-}, \mathrm{D}-\mathrm{cNO}_{3}^{-}$, and $\mathrm{cNO}_{3}^{-}$accompanied by $\mathrm{cNH}_{4}^{+}$, respectively. The MRA results showed a high correlation, $\mathrm{R}^{2}=0.74$, and clearly explained the observed seasonal changes. The annual average contributions of the component were $40 \%\left(\mathrm{SS}_{-} \mathrm{cNO}_{3}^{-}\right), 20 \%\left(\mathrm{D}-\mathrm{cNO}_{3}^{-}\right)$, and $40 \%\left(\mathrm{cNH}_{4}^{+}\right.$term). The $\mathrm{D}_{-} \mathrm{cNO}_{3}^{-}$component had the largest value during the dust season, and the sea salt component made a large contribution throughout the year. $\mathrm{CNH}_{4}^{+}$made a large contribution during the winter; one possible reason for this was the condensation/coagulation of small $\mathrm{NH}_{4} \mathrm{NO}_{3}$ and $\left(\mathrm{NH}_{4}\right)_{2} \mathrm{SO}_{4}$ particles onto large particles (e.g., dust and sea salt).
The present model did not include aerosol microphysical processes (such as condensation and coagulation between fine anthropogenic aerosols, such as $\mathrm{NO}_{3}^{-}$and $\mathrm{SO}_{4}^{2-}$, and coarse particles), but our results suggest that aerosol microphysical processes are important for studying observed $\mathrm{cNO}_{3}^{-}$formation, especially in winter.

Code and data availability. To request the observation data used in this study for scientific research purposes, please contact Itsushi Uno at Kyushu University via email (uno@riam.kyushu-u.ac.jp). The model simulations were based on GEOS Chem, open-source and publicly available software. The model and related software can be downloaded from http://acmg.seas.harvard.edu/geos/ by registered users (GEOS-Chem Steering Committee, 2017). 


\section{Appendix A}

During the SVolc period (shown in Fig. 3), two typhoons passed south of Japan from east to west. Figure A1 shows snapshots of the trajectories and wind fields of Typhoon Halola (T12) and Typhoon Soudelor (T13), along with modeled $\mathrm{SO}_{4}^{2-}$ concentrations.

$\mathrm{SO}_{4}^{2-}$ in the northern part of Japan and Korea were under the control of LRT from China, while the southern part of Japan was covered by east winds (due to typhoons). This indicated that the high $\mathrm{SO}_{4}^{2-}$ concentrations in Fukuoka were due to Japanese domestic emissions and the impact of Mt. Sakurajima volcano (typically 2-6 August). Note that the estimated $\mathrm{SO}_{2}$ emission from Mt. Sakurajima is around $10^{3} \mathrm{Gg}$ year ${ }^{-1}$, which is almost equivalent to the level of anthropogenic $\mathrm{SO}_{2}$ emissions in Japan.

Figure A2 shows the volcano sensitivity experiment (VOFF) for $\mathrm{SO}_{4}^{2-}$. It is clear that the impact of the volcano was higher for the period 2-6 August; during this period, $\mathrm{SO}_{4}^{2-}$ contributions converted from volcanic $\mathrm{SO}_{2}$ emission exceeded $50 \%$ of the total $\mathrm{SO}_{4}^{2-}$. Observations show higher values from 27 July to 1 August, and the model simulation failed to describe this. Volcanic emissions are natural phenomena and have strong day-by-day variation, so this failure of the model is due to underestimation of volcanic emissions during this period. 


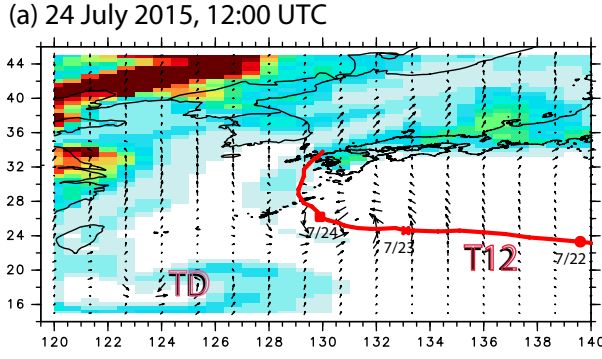

(c) 30 July 2015, 00:00 UTC

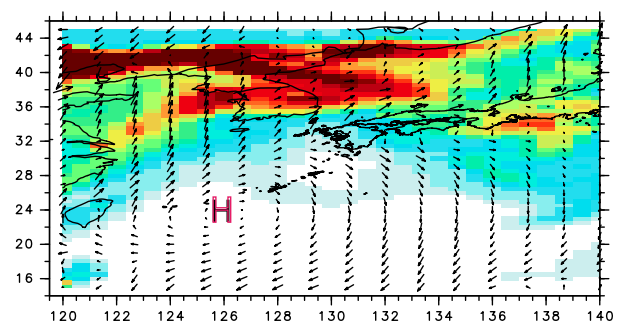

(e) 6 August 2015, 00:00 UTC

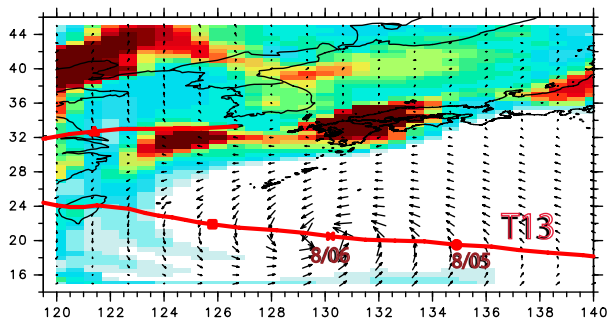

(b) 24 July 2015, 12:00 UTC

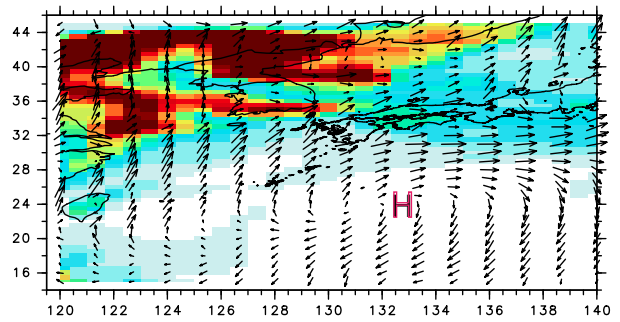

(d) 2 August 2015, 12:00 UTC

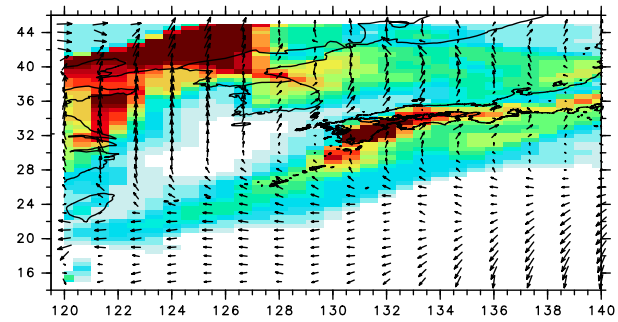

(f) 7 August 2015, 00:00 UTC
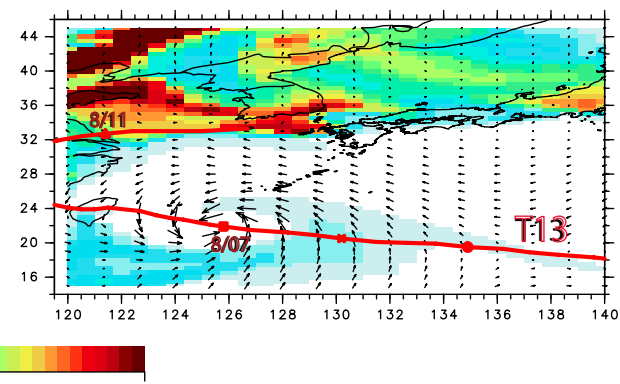

Figure A1. Horizontal distribution of fine $\mathrm{SO}_{4}^{2-}$ (color) with wind vectors from model's first vertical level (65 m). The red line indicates the trajectory of Typhoon Halola (T12) in panel (a), and Typhoon Soudelor (T13) in panels (e) and (f).

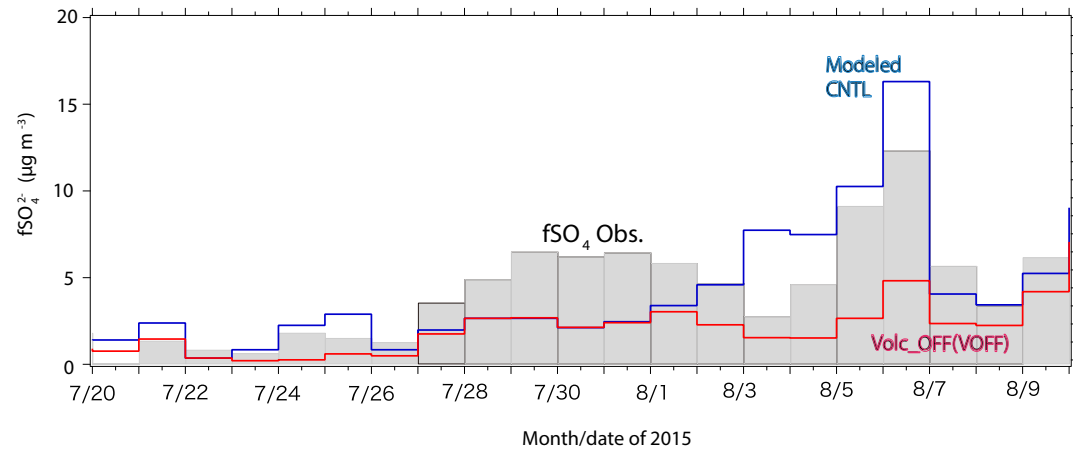

Figure A2. Daily average variation in observed (gray shading) and modeled fine $\mathrm{SO}_{4}^{2-}$ (blue line is CNTL and red line is VOFF). 
Author contributions. IU designed the synergetic observations at Chikushi Campus of Kyushu University, Japan. SY and KO carried out the ground-based ACSA and $\mathrm{NH}_{x}$-monitor observations, respectively, at Fukuoka. KO conducted air sampling and chemical analysis of D-F pack samples during the observation period at Fukuoka. YK and XP conducted the CO observations at Fukuoka. TDF provided the GEOS Chem modeling system. IU, KY, SI, and ZW performed the model simulations and analysis and prepared the paper with contributions from all coauthors.

Competing interests. The authors declare that they have no conflicts of interest.

Special issue statement. This article is part of the special issue "Global and regional assessment of intercontinental transport of air pollution: results from HTAP, AQMEII and MICS". It is not associated with a conference.

Acknowledgements. This work was supported by the Ministry of Education, Culture, Sports, Science and Technology (MEXT), the Japan Society for the Promotion of Science (JSPS), and the Grants-in-Aid for Scientific Research (KAKENHI) program (grant JP25220101). The authors would like to thank the developers of the GEOS reanalysis product. This work was partly funded by a collaborative research program through the Research Institute for Applied Mechanics at Kyushu University (nos. 26AO-2, 27AO-6, 28AO-2). We thank Yusuke Kamiguchi at Nagoya University for the D-F pack sampling and chemical analysis and Shohei Kuwahara at Kyushu University for the D-F pack sampling.

Edited by: Kostas Tsigaridis

Reviewed by: two anonymous referees

\section{References}

Appel, B. R., Tokiwa, Y., and Haik, M.: Sampling of nitrates in ambient air, Atmos. Environ., 15, 283-289, 1981.

Bey, I., Jacob, J., Yantosca, R. M., Logan, A., Field, B. D., Fiore, A. M., Li, Q., Liu, H. Y., Mickley, J., and Schultz, M. G.: Global modeling of tropospheric chemistry with assimilated meteorology: Model description and evaluation, J. Geophys. Res., 106, 73-95, 2001.

Boylan, J. W. and Russell, A. G.: PM and light extinction model performance metrics, goals, and criteria for three-dimensional air quality models, Atmos. Environ. 40, 4946-4959, 2006.

EANET: EANET and Clean Air for Sustainable Development. The Third Report for Policy Makers (RPM3), Acid Deposition Monitoring Network in East Asia (EANET), Pathumthani, Thailand, 2014.

Fairlie, T. D., Jacob, D. J., and Park, R. J.: The impact of transpacific transport of mineral dust in the United States, Atmos. Environ., 41, 1251-1266, 2007.

Fairlie, T. D., Jacob, D. J., Dibb, J. E., Alexander, B., Avery, M. A., van Donkelaar, A., and Zhang, L.: Impact of mineral dust on nitrate, sulfate, and ozone in transpacific
Asian pollution plumes, Atmos. Chem. Phys., 10, 3999-4012, https://doi.org/10.5194/acp-10-3999-2010, 2010.

GEOS-Chem Steering Committee: GEOS-Chem Model, available at: http://acmg.seas.harvard.edu/geos/, last access: 13 November 2017.

Ginoux, P., Chin, M., Tegen, I., Prospero, J. M., Holben, B., Dubovik, O., and Lin, S.-J.: Sources and distributions of dust aerosols simulated with the GOCART model, J. Geophys. Res., 106, 20255-20274, 2001.

Ginoux, P., Prospero, J. M., Torres, O., and Chin, M.: Long-term simulation of global dust distribution with the GOCART model: correlation with North Atlantic Oscillation, Environ. Modell. Softw., 19, 113-128, 2004.

Hasegawa, S., Wakamatsu, S., and Tanabe, K.: Parallel measurement test of black carbon monitors, Proceeding of 21th Symposium on Aerosol Science and Technology, Japan Association of Aerosol Science and Technology, p. 7, 2004 (in Japanese).

He, H., Wang, Y., Ma, Q., Ma, J., Chu, B., Ji, D., Tang, G., Liu C., Zhang, H., and Ho, J.: Mineral dust and NOx promote the conversion of $\mathrm{SO}_{2}$ to sulfate in heavy pollution days, Scientific Reports, 4, 4172, https://doi.org/10.1038/srep04172, 2014.

Huang, X., Song, Y., Li, M., Li, J., Cai, X., Zhu, T., Hu, M., and Zhang, H.: A high-resolution ammonia emission inventory in China, Global Biogeochem. Cy., 26, GB1030, https://doi.org/10.1029/2011GB004161, 2012.

Huebert, B. J., Bates, T., Russell, P. B., Shi, G., Kim, Y. J., Kawamura, K., Carmichael, G., and Nakajima, T.: An overview of ACE-Asia: Strategies for quantifying the relationships between Asian aerosols and their climatic impacts, J. Geophys. Res., 108, 8633, https://doi.org/10.1029/2003JD003550, 2003.

Irie, H., Muto, T., Itahashi, S., Kurokwa, J., and Uno, I.: Turnaround of tropospheric nitrogen dioxide pollution trends in China, Japan, and South Korea, SOLA, 12, 170-174, https://doi.org/10.2151/sola.2016-035, 2016.

Itahashi, S., Hayami, H., and Uno, I.: Comprehensive study of emission source contributions for tropospheric ozone formation over East Asia, J. of Geophys. Res, 120, 331-358, 2015.

Itahashi, S., Hayami, H., Uno, I., Pan, X., and Uematsu, M.: Importance of coarse-mode nitrate produced via sea salt as atmospheric input to east Asian oceans, Geophys. Res. Lett., 43, https://doi.org/10.1002/2016GL068722, 2016.

Itahashi, S., Uno, I., Osada, K., Kamiguchi, Y., Yamamoto, S., Tamura, K., Wang, Z., Kurosaki, Y., and Kanaya, Y.: Nitrate transboundary heavy pollution over East Asia in winter, Atmos. Chem. Phys., 17, 3823-3843, https://doi.org/10.5194/acp17-3823-2017, 2017.

Jacob, D.: Heterogeneous chemistry and tropospheric ozone, Atmos. Environ., 34, 2131-2159, 2000.

Jacob, D., Crawford, J., Kleb, M., Conners, V., Bendura, R., Raper, J., Sachse, G., Gille, J., and Emmons, L.: Transport and chemical evolution over the Pacific (TRACE-P) mission: Design, execution, and overview of first results, J. Geophys. Res., 108, 8781, https://doi.org/10.1029/2002JD003276, 2003.

Jaeglé, L., Quinn, P. K., Bates, T. S., Alexander, B., and Lin, J.-T.: Global distribution of sea salt aerosols: new constraints from in situ and remote sensing observations, Atmos. Chem. Phys., 11, 3137-3157, https://doi.org/10.5194/acp-11-3137-2011, 2011. 
John, W., Hering, S., Reischl, G., Sasaki, G., and Goren, S.: Characteristics of nuclepore filters with large pore size-II. Filtration properties, Atmos. Environ., 17, 373-382, 1983.

Keene, W. C., Pszenny, A. A. P., Galloway, J. N., and Hawley, M. E.: Sea-salt corrections and interpretation of constituent ratios in marine precipitation, J. Geophys. Res., 91, 6646-6658, 1986.

Kimoto, H., Ueda, A., Tsujimoto, K., Mitani, Y., Toyasaki, Y., and Kimoto, T.: Development of continuous dichotomous aerosol chemical speciation analyzer, Clean Technol., 23, 49-52, 2013 (in Japanese).

KORUS-AQ: https://espo.nasa.gov/home/korus-aq/content/ KORUS-AQ (last access: 13 November 2017), 2016.

Kurokawa, J., Ohara, T., Morikawa, T., Hanayama, S., JanssensMaenhout, G., Fukui, T., Kawashima, K., and Akimoto, H.: Emissions of air pollutants and greenhouse gases over Asian regions during 2000-2008: Regional Emission inventory in ASia (REAS) version 2, Atmos. Chem. Phys., 13, 11019-11058, https://doi.org/10.5194/acp-13-11019-2013, 2013.

Lawrence, M. G. and Lelieveld, J.: Atmospheric pollutant outflow from southern Asia: a review, Atmos. Chem. Phys., 10, 1101711096, https://doi.org/10.5194/acp-10-11017-2010, 2010.

Li, J., Wang, Z., Zhuang, G., Luo, G., Sun, Y., and Wang, Q.: Mixing of Asian mineral dust with anthropogenic pollutants over East Asia: a model case study of a superduststorm in March 2010, Atmos. Chem. Phys., 12, 7591-7607, https://doi.org/10.5194/acp-12-7591-2012, 2012.

Li, J., Du, H., Wang, Z., Sun, Y., Yang, W., Li, J., Tang, X., and Fu, P.: Rapid formation of a severe regional winter haze episode over a mega-city cluster on the North China Plain, Environ. Pollut., 223, 605-615, 2017.

Li, W. J. and Shao, L. Y.: Observation of nitrate coatings on atmospheric mineral dust particles, Atmos. Chem. Phys., 9, 18631871, https://doi.org/10.5194/acp-9-1863-2009, 2009.

Oita, A., Malik, A., Kanemoto, K., Geschke, A., Nishijima, S., and Lenzen, M.: Substantial nitrogen pollution embedded in international trade. Nat. Geosci. 9, 111-115, 2016.

Olivier, J. G. J. and Berdowski, J. J. M.: Global emissions sources and sinks, in: The Climate System, edited by: Berdowski, J., Guicherit, R., and Heij, B. J., A. A. Balkema Publishers/Swets \& Zeitlinger Publishers, Lisse, The Netherlands, 33-78, 2001.

Osada, K., Ueda, S., Egashira, T., Takami, A., and Kaneyasu, N.: Measurement of gaseous $\mathrm{NH}_{3}$ and particulate $\mathrm{NH}_{4}^{+}$in the atmosphere by fluorescent detection after continuous airwater droplet sampling, Aerosol Air Qual. Res., 11, 170-178, https://doi.org/10.4209/aaqr.2010.11.0101, 2011.

Osada, K., Kamikuchi, T., Yamamoto, S., Kuwahara, S., Pan, X., Hara, Y., Uno, I.: Comparison of ionic concentrations on sizesegregated atmospheric aerosol particle based on a denuer-filter method and a Continuous Dichotomous Aerosol Chemical Speciation Analyzer (ACA-12), Earozoru Kenkyu, 31, 203-209, 2016 (in Japanese with English abstract).

Pan, X., Uno, I., Hara, Y., Kuribayashi, M., Kobayashi, H., Sugimoto, N., Yamamoto, S., Shimohara, T., and Wang, Z.: Observation of the simultaneous transport of Asian mineral dust aerosols with anthropogenic pollutants using a POPC during a long-lasting dust event in late spring 2014, Geophys. Res. Lett., 42, 1593-1598, 2015.

Pan, X., Uno, I., Hara, Y., Osada, K., Yamamoto, S., Wang, Z., Sugimoto, N., Kobayashi, H., and Wang, Z.: Polarization properties of aerosol particles over western Japan: classification, seasonal variation, and implications for air quality, Atmos. Chem. Phys., 16, 9863-9873, https://doi.org/10.5194/acp-16-9863-2016, 2016.

Pan, X., Uno, I., Wang, Z., Nishizawa, T., Sugimoto, N., Yamamoto, S., Kobayashi, H., Sun, Y., Fu, P., Tang, X., and Wang, Z.: Realtime observational evidence of changing Asian dust morphology with the mixing of heavy anthropogenic pollution, Scientific Reports, 7, 335, https://doi.org/10.1038/s41598-017-00444w, 2017.

Park, R. J., Jacob, D. J., Field, B. D., Yantosca, R. M., and Chin, M.: Natural and transboundary pollution influences on sulphate-nitrate-ammonium aerosols in the United States: implications for policy, J. Geophys. Res., 109, D15204, https://doi.org/10.1029/2003JD004473, 2004.

Perrino, C., Santis, F. D., and Febo, A.: Criteria for the Choice of a Denuder Sampling Technique Devoted to the Measurement of Atmospheric Nitrous and Nitric Acids, Atmos. Environ., 24, 617-626, 1990.

Richter, A., Burrows, J. P., Nüß, H., Granier, C., and Niemeier, U.: Increase in tropospheric nitrogen dioxide over China observed from space, Nature, 437, 129-132, https://doi.org/10.1038/nature04092, 2005.

Roelle, P. A. and Aneja, V. P.: Characterization of ammonia emissions from soils in the upper coastal plain, North Carolina. Atmos. Environ., 36, 1087-1097, 2002.

Sugimoto, N., Matsui, I., Shimizu, A., Nishizawa, T., Hara, Y., Xie, C., Uno, I., Yumimoto, K., Wang, Z., and Yoon, S.-C.: Lidar network observations of tropospheric aerosols, SPIE 7153, https://doi.org/10.1117/12.806540, 2008.

Uno, I., Yumimoto, K., Pan, X. L., Wang, Z., Osada, K., Itahashi, S., and Yamamoto, S.: Simultaneous dust-pollutants transport over East Asia: the Tripartite Environment Ministers Meeting March 2014 Case Study, SOLA, 13, 47-52, https://doi.org/10.2151/sola.2017-009, 2017a.

Uno, I., Osada, K., Yumimoto, K., Wang, Z., Itahashi, S., Pan, X., Hara, Y., Yamamoto, S., and Nishizawa, T.: Importance of longrange nitrate transport based on longterm observation and modeling of dust and pollutants over East Asia, Aerosol Air Qual. Res., 17, 3052-3064, https://doi.org/10.4209/aaqr.2016.11.0494, 2017b.

Vecchi, R., Valli, G., Fermo, P., D’Alessandro, A., Piazzalunga, A., and Bernardoni, V.: Organic and inorganic sampling artefacts assessment, Atmos. Environ., 43, 1713-1720, 2009.

Wang, Z., Pan, X., Uno, I., Li, J., Wang, Z., Chen, X., Fu, P., Yang, T., Kobayashi, H., Shimizu, A., Sugimoto, N., and Yamamoto, S.: Significant impacts of heterogeneous reactions on the chemical composition and mixing state of dust particles: A case study during dust events over northern China, Atmos. Environ., 159, 83-91, 2017a.

Wang, Z., Pan, X., Uno, I., Li, J., Wang, Z., Sugimoto, N., and Yamamoto, S.: Modeling the long-range transport of particulate matters during winter in East Asia using NAQPMS and CMAQ, Aerosol Air Qual. Res., 17, 3065-3078, https://doi.org/10.4209/aaqr.2016.12.0534, 2017b.

Xu, P., Zhang, Y., Gong, W., Hou, X., Kroeze, C., Gao, W., and Luan, S.: An inventory of the emission of ammonia from agriculture fertilizer application in China for 2010 and its highresolution spatial distribution, Atmos. Environ. 115, 141-148, 2015 . 
Yu, F. and Luo, G.: Modeling of gaseous methylamines in the global atmosphere: impacts of oxidation and aerosol uptake, Atmos. Chem. Phys., 14, 12455-12464, https://doi.org/10.5194/acp-1412455-2014, 2014

Yumimoto, K., Uno, I., Pan, X., Nishizawa, T., and Kim, S.-W.: Inverse Modeling of Asian Dust Emission with POPC Observations for TEMM DSS 2014 Case Study, SOLA, 13, 31-35, https://doi.org/10.2151/sola.2017-006, 2017.

Zender, C. S., Bian, H., and Newman, D.: Mineral Dust Entrainment and Deposition (DEAD) model: Description and 1990s dust climatology, J. Geophys. Res., 108, 4416, https://doi.org/10.1029/2002JD002775, 2003.
Zhang, Q., Jiang, X., Tong, D., Davis, S. J., Zhao, H., Geng, G., Feng, T., Zheng, B., Zifeng, L., Streets, D. G., Ni, R., Brauer, M., van Donkelaar, A., Martin, R. V., Huo, H., Liu, Z., Da Pan, D., Kan, H., Yan, Y., Lin, J., He, K., and Guan, D.: Transboundary health impacts of transported global air pollution and international trade, Nature, 543, 705-709, https://doi.org/10.1038/nature21712, 2017. 